\title{
INVENTORY CONTROL METHODS IN INDUSTRY 4.0 IMPLEMENTATIONS
}

\author{
DOI: 10.17261/Pressacademia.2018.991 \\ JMML- V.5-ISS.4-2018(6)-p.324-340
}

Gozde Hilal Kilic ${ }^{1}$, Melis Gizem Ozturk², Ahmet Murat Koseoglu ${ }^{3}$

${ }^{1}$ Okan University, Tepeören Mahallesi, Okan Üniversitesi Tuzla Kampüsü, 34959 Tuzla, Istanbul, Turkey. gozdehilalkilic0@gmail.com, ORCID: 0000-0002-2105-3502

${ }^{2}$ Okan University, Tepeören Mahallesi, Okan Üniversitesi Tuzla Kampüsü, 34959 Tuzla, Istanbul, Turkey. melis.ozturk@okan.edu.tr, ORCID: 0000-0001-7927-8467

${ }^{3}$ Okan University, Tepeören Mahallesi, Okan Üniversitesi Tuzla Kampüsü, 34959 Tuzla, Istanbul, Turkey. murat.koseoglu@okan.edu.tr, ORCID: 0000-0002-0656-2798

Date Received: August 31, 2018

Date Accepted: December 9, 2018

To cite this document

Kilic, G. H., Ozturk, M. G., Koseoglu, A. M. (2018). Inventory control methods in industry 4.0 implementations. Journal of Management, Marketing and Logistics (JMML), V.5(4), p.324-340.

Permemant link to this document: http://doi.org/10.17261/Pressacademia.2018.991

Copyright: Published by PressAcademia and limited licenced re-use rights only.

\begin{abstract} investigated in the enterprises using Industry 4.0 in production. backed inventory control systems to be used in future logistics businesses. methods inventory control methods are changing and Industry 4.0 is becoming more focused the change process that firms will be forced to adapt to Industry 4.0.

Keywords: Industry 4.0, logistics, smart factories, stock control methods, supply chain management.

JEL Codes: L9, L9O, L99
\end{abstract}

Purpose- With Industry 4.0, manufacturing companies are undergoing an exchange process with new production methods. This change process affects not only the production stages of the firms but also the stock control methods. In this study, inventory control methods were

Methodology- A case study from qualitative research methods was used in the research. In the first part of this study, literature review was carried out, inventory control processes, problems in inventory control processes, purposes and forms of Industry 4.0 technologies were examined. In the next part of the study, we were presented the industry-supported inventory control methods used today and the industry-

Findings- Manufacturing methods have emerged with Industry 4.0 and this methods have not been changed before. With the effect of this

Conclusion- The Industry 4.0 concept, which is still under development, affects not only every sub-component that is connected to the firm but also the production angle of the companies that produce the concept. In response to this situation, stock control methods are also affected by

\section{ÜRETIMDE ENDÜSTRI 4.0 KULLANAN IŞLETMELERDE STOK KONTROL YÖNTEMLERi}

\section{ÖZET}

Amaç - Endüstri 4.0 ile birlikte üretici firmalar yeni üretim yöntemleri ile birlikte bir değişim sürecinden geçmektedir. Bu değişim süreci firmaların sadece üretim aşamalarını değil aynı zamanda stok kontrol yöntemlerini de etkilemektedir. Bu çalışmada, üretimde Endüstri 4.0 kullanan işletmelerde stok kontrol yöntemleri araştırılmıştır.

Yöntem - Araştırma nitel araştırma yöntemlerinden örnek olay çalışması ile yapılmıştır. Bu kapsamda çalışmanın ilk bölümlerinde literatür taraması gerçekleştiri Imiş, stok kontrol süreçleri, stok kontrol süreçlerindeki problemler, Endüstri 4.0 teknolojilerinin amaçları ve şekilleri incelenmiştir. Sonraki bölümünde, uluslararası alanda tedarik zincir ve lojistik yönetimi yapan ve arge merkezi bir işletmenin uygulamaları incelenmiştir. Çalışmanın sonuç ise bölümünde günümüzde kullanılan endüstri 4.0 destekli stok kontrol yöntemleri ile gelecekte kullanılacak endüstri 4.0 destekli stok kontrol sistemleri ile ilgili değerlendirmelerde bulunulmuştur.

Bulgular- Endüstri 4.0 ile ortaya çıkan ve daha önce olmayan üretim yöntemlerinin etkisi ile stok kontrol yöntemleri de değişmekte ve Endüstri 4.0 odaklı hale gelmektedir.

Sonuç- Halen gelişim sürecinde olan Endüstri 4.0 konsepti üretim yapan firmaların sadece üretim açısını değil işletmeye bağlı bulunan her alt parçayı etkilemektedir. Bu durum karşısında Endüstri 4.0’a uyum sağlamak için işletmelerin geçireceği değişim sürecinden stok kontrol yöntemleri de etkilenmektedir.

Anahtar Kelimeler: Akıllı fabrikalar, endüstri 4.0, lojistik, stok kontrol süreçleri, tedarik zinciri yönetimi.

JEL Kodları: L9, L90, L99 


\section{Giriş}

Endüstri devriminin başlangıcından günümüze kadar olan süreçte teknolojik gelişmeler, özellikle bilgi teknolojileri, mobil iletişim ve e-ticaret ile karşılaştırıldığında işletmelere büyük maliyetler getirmiştir. Çağımızın ihtiyaçlarını karşılamak ve aynı zamanda maliyet kazancı ve güvenilirlik sağlamak, kısa zamanda doğru bilgiye ulaşmak maksadıyla işletmelerin endüstri 4.0 uygulamalarından faydalanmaları doğru bir seçenek olarak gözükmektedir.

Yeni endüstri devrimi olarak kabul edilen Endüstri 4.0, üretimde ve tüm iş süreçlerinde teknolojiye dayanmaktadır. Lojistik, müşterilerden gelen talep değişikliklerine göre şekillenen bir sistemdir. Lojistik kavramının önemli bir parçası olan stok kontrolü ile, yeni sanayi devrimi, Endüstri 4.0 stok kontrol kavramını yeni bir meydan okuma ile karşı karşıya bırakmaktadır. Endüstri 4.0'ın diğer sanayi devrimlerinden farkı, Endüstri 4.0, yeni bir buluş ile değil, yenilikçi bir yaklaşımın sonucu olmasıdır. Bu yenilikçi yaklaşımın nedeni, dünyanın insanlar için kısa sürede yeterli olmayacağı ve bu durumun işletmelerde sorunlara yol açacağı gerçeğidir. Bununla birlikte, Endüstri 4.0'ın otomasyon ve diğer özellikleriyle, bu sorun çözülebilir hale getirilmeyi hedeflenmektedir.

Önemli bir hizmet olarak lojistik, doğru müşterilere doğru ürünleri doğru zamanda sunmayı hedeflediği için işletmelerdeki her değişiklikten etkilenecektir. Bu nedenle, lojistik şirketleri sektördeki her değişikliğe cevap vermelidir. İşletmedeki değişimlere cevap vermek için, stok kontrol yöntemleri de bu sürece bağlı olarak değişiklik göstermelidir.

Geleneksel yöntemlerden dijital yöntemlere doğru geçiş yaşadığımız süreçte, bilgi teknolojilerinin çoğu birbiri ile bütünleşmiş değildir. Sadece şirketler, tedarikçiler ve müşteriler kısmen yakından bağlantılıdır. Endüstri 4.0 uygulamaları ile üretim ve hizmet bölümleri de birbiri ile bütünleşmiş hale gelerek, stok kontrol aşamalarında yatay ve dikey sistem uyumunun sağlanabileceği öngörülmektedir.

Yapılan çalışmada, stok kavramı ve endüstri 4.0 ile olan ilişkisi incelenmiştir. Stok yöntemi, stok kontrol kavramı ve stok kontrol yöntemleri incelenmiştir. Stok yönteimi üretim sistemlerinin aksamadan devam etmesi için firmalar tarafından hayati bir önem taşımaktadır. Stok yönetiminin önemi firmalar için Endüstri 4.0 kapsamında gelecek olan değişiklikleri, firmaların içselleştirebilmesi açısından önemlidir. Her yeni üretim yönteminin benimsenmesi, stok yönetimindeki değişiklikleri beraberinde getirmektedir. Stok yönetiminin yapıtaşlarından olan hammaddeler, yarı mamüller, nihai mamüller, hazır parça stokları ve yardımcı malzemeler üretim yöntemlerinin değişmesi ile birlikte farklılaşmakta, bu farklılaşmanın sonucu olarak da stok yönetim biçimleri de farklılaşmaktadır.

Stok kontrolü genel olarak dört gruba ayrılan hammadde stokları, yarı mamul stokları, ürün stokları ve yardımcı madde stokları ile elde edilen ürün/ hizmet için kullanılan her türlü malzemeye uygulanabilir. Stok kontrol sürecinin temel amacını, stoklara yapılacak en optimum yatırımı belirleyerek, en düşük maliyetle müşterilerin ihtiyaçlarını karşılamak şeklinde açıklanabilir. Stok kontrolü de stok yönetimi gibi üretim yöntemlerinin farklılaşmasından etkilenmektedir. Optimal yatırım rekabetçiliğin son derece yüksek olduğu ve buna bağlı olarak kar marjlarının düşük olduğu günümüz piyasa koşullarında firmaların devamlıı̆ı için hayati bir önem taşımaktadır. Optimal yatırımın kaynaklarından biri olan stok kontrol yönetimi firmaların son derece maliyetli olan endüstri 4.0 uygulamalarından verim alabilmeleri için kaynaklardan birini oluşturmaktadır.

Endüstri 4.0, üretim ve ticaret alanındaki otomasyona dayalı yeni sanayi devrimini temsil etmektedir. Endüstri 4.0, 2011 yılında "Yüksek Teknoloji Stratejisi 2020 Eylem Planı" nın bir parçası olarak kabul edilen Alman hükümetinin stratejik bir girişimidir (Kagermann, Wahlster, Helbig, 2013). Bununla birlikte, Endüstri 4.0, gerçeklikten ziyade hala bir vizyon, bu nedenle, bahsedilen bazı özellikler henüz etkilerini göstermiyor. Endüstri 4.0 vizyonu, dijitalleştirilmiş bir üretim süreci için Hannover Messe 2011'de başladı. Almanya, Siber-Fiziksel Sistem destekli üretim ve hizmet yeniliğine dayalı olarak 4. Nesil Sanayi Devrimi'ne (Endüstri 4.0) doğru bir dönüşüme liderlik ediyor. Endüstriyel ürünlere ve sistemlere entegre edilen daha fazla yazılım ve gömülü zeka, akıllı teknolojiler ile elektronik algoritmaları ve zahmetsiz zekayı bir araya getirebilir. Bu teknolojiler daha sonra ürün performansı bozulmasını tahmin etmek ve ürün hizmet ihtiyaçlarını özerk bir şekilde yönetmek ve optimize etmek için kullanılacaktır (Lee, Kao ve Yang, 2014).

Endüstri 4.0'ın sunduğu avantajlardan biri ise bilgi aktarımının fazlalığıdır. Bu durum firmaların önemli stok problemlerinden biri olan sipariş zamanlaması ile ilgili avantajlar sağlayabilecek düzeye getirebilecek bir yapı taşıdır. Firmaların endüstri 4.0 ile uyum sağlaması gereken süreçler olduğu kadar, endüstri 4.0 ile hali hazırda var olan problemlerine cevap bulabilme ihtimali de bulunmaktadır. Çalışmada stok kavramı ile endüstri 4.0'ın ilişkisi incelenirken, hem endüstri 4.0 ile gelen stok kavramı değişikliklerinin yaratacağı dezavantajlar hem de avantajlar incelenmiştir. Yapılan incelemeler, hali hazırda endüstri 4.0 kullanana lojistik firmalarından elde edilen verilere, ikincil kaynaklara ve internet araştırmalarına dayandırılmıştır. 


\section{LITERATÜR INCELEMESi}

\subsection{Stok Yönetimi}

Stoklar; üretim sistemlerinin aksamadan devam edebilmesi, siparişlerin doğru miktarda, doğru zamanda, doğru yere teslim edilmesi ve müşteri memnuniyeti açısından büyük önem arz etmektedir. Stoklar ayrıca işletmelerin yatırım kalemlerinin önemli bir bölümünü oluşturmaktadır. Stokların bu önemi, sipariş, stok ve ürün takibi, teslimat gibi birbiri ile bağlantılı birçok fonksiyonun uyumlu bir sistem halinde çalışmasını zorunlu hale getirmektedir.

Stok kavramının tanımına bakacak olursak; üretim sistemlerinde bulunan her türlü hizmet ve mala doğrudan veya dolaylı olarak katılan tüm fiziksel nesnelerin maliyetidir. (Tekin, 2003) Başka bir tanıma göre; depolanan her türlü nesne stok olarak kabul edilir. Stoklar, stok olarak nitelendirilen nesnelerin miktarı ve parasal karşılığı ile ölçülür. (Kobu, 2014) Stoklar genel olarak hammadde, yarı mamul ve nihai mamul olmak üzere üç kategoride sınıflandırılır. Ayrıca üretilen ürünlere doğrudan katılmayan yardımcı malzemeler ve hazır parçalar bulunmaktadır.

Hammadde Viale (1996) bir ürünü son haline getirebilmek amacı ile satın alınan bütün ürün ve parçaları stok olarak değerlenirmektedir. Ürün içeriğini oluşturan, değer katan parçalar bir araya gelerek stok kavramını yaratmaktadır. Kobu hammadde kavramını işletmeden işletmeye değişebileceğini vurgulamıştır. Ona göre hammadde üretim sisteminde sahip olduğu niteliğe göre belirlenmektedir. Demir çelik üretimi ile ilgilenen bir işletme için pik mamül görevi görürken radyatör üreticisi bir işletme için pik hammaddedir.

Yarı mamuller; Sulak (2008) bu kavramı henüz işlemleri tamamlanmamış ve istasyonlar arasında hareket eden veya bekleyen, zaman içerisinde tamamlanarak nihai mamül haline gelecek nesneler olarak tanımlamıştır.

Nihai mamuller; tüm üretim aşamalarından geçerek tamamlanmış ve satışa hazır olan varlıklar olarak ifade edilir. Mamuller, toptancı ve perakendeci gibi farklı satış yerlerine gönderilmek amacıyla stokta bulundurulur. (Tanyaş ve Baskak, 2006)

Hazır parça stokları, mamullerin bir bölümünü oluşturan ve çoğunlukla dışardan tedarik edilen nesnelerdir. Bu mamüller; sık kullanılan parçalar olabileceği gibi sadece belirli zamanlarda ihtiyaç duyulan mamüller de olabilir. (Kobu, 2014).

Yardımcı malzemeler; Nihai ürünün üretiminde faydalanılan fakat ürünün temel malzemesi olmayan nesnelerdir. İşletmede üretim sürecinde bütün aşamalarda kullanılan yardımcı malzemeler işletmeden işletmeye farklılık göstermektedir.

Hammadde, yarı mamul ve mamul stokları, işletmenin üretimini yaptığı mamule göre değişiklik gösterebilir. Örneğin; bir işletme için hammadde stoğu olan bir malzeme diğer bir işletme için mamul olabilir. Bu durum işletmenin elindeki stoka herhangi bir katma değer ekleyip yeni bir mamul elde edip etmemesine göre değişir.

Küreselleşen dünyada, işletmelerin müşteri ihtiyaçlarına kısa sürede cevap verme ihtiyacı giderek artmaktadır. Bu duruma bağlı olarak, piyasada işletmeler arası ciddi rekabet ortamı oluşmaktadır. İşletmelerin oluşan rakabet ortamı ile mücadele edebilmesi ve piyadaki yerlerini koruyabilmesi için işletme maliyetlerini azaltmaları gerekmektedir. İşletmelerin maliyetlerini azaltabilmesi için doğru ve etkin şekilde oluşturulan stok yönetimine ihtiyaç duymaktadırlar.

Stok yönetimi; işletmenin üretim, satış ve finansal koşulları göz önünde bulundurularak, işletmenin yapısına göre en ekonomik stok miktarını belirlemeyi ve bu miktarı aynı seviyede tutmayı amaçlar. Tekin(2009) stok yönetimini süreci daimi bir şekilde izleyen ve en az yatırım ile maksimum fayda sağlayan hizmetlerin verilmesi olarak tanımlamıştır. Optimal hizmetler, stok ile ilgili sorunlar yaşama riski minimize edilerek işletme karının maksimize edilmesi ile gerçekleşmektedir.

\subsection{Stok Kontrolü}

Stok kontrolü genel olarak dört gruba ayrılan hammadde stokları, yarı mamul stokları, ürün stokları ve yardımcı madde stokları ile elde edilen ürün/ hizmet için kullanılan her türlü malzemeye uygulanabilir. Stok kontrol sürecinin temel amacını, stoklara yapılacak en optimum yatırımı belirleyerek, en düşük maliyetle müşterilerin ihtiyaçlarını karşılamak şeklinde açıklayabiliriz.

Günay (2005) stok kontrolünü stok yönetimi bölümünde tanımlanan bütün kavramların bir araya gelerek nihai ürünün ortaya çıkmasını fakat gereğinden fazla birikim olmamasını sağlamak amacı ile yapılan işlemler olarak açıklamıştır. "Stok kontrolünün tanımından da anlaşılacağı üzere, işletmelerin etkin bir stok kontrolü gerçekleştirebilmeleri için üretim sürecinde yer alan tüm maddeleri uygun miktarlarda stoklarda bulundurmalı, takibini yapmalı ve üretimin aksamadan devam etmesini sağlamalıdır. İşletmeler için tüm bu işlemler stok miktarını düşük tutmak anlamına gelmez; genellikle gereken her duruma yetecek stoku en düşük maliyetle bulundurabilme anlamındadır" (Doğan, 1995). Bu işlemler sayesinde toplam stok maliyetlerini minimize edebilecek bir stok düzeyine erişme olanağı elde edilmektedir. Bu sebeple tüm işletmeler; kendi yapısına, mali gücüne, ürettiği mal ve hizmetin çeşidine göre bir stok kontrol sistemi belirler ve uygular. (Ayanoğlu, 2005) 
Sipariş mikarı ve stok maliyeti arasında ters bir orantı söz konusudur. İşletmeler büyük miktarda sipariş verdiklerinde, sipariş maliyeti azalır ancak bu durum stok maliyetini arttırır. Stok maliyetini azalmak için düşük miktarda sipariş verilmesi halinde ise sipariş maliyeti artar ve işletmenin ani olarak değişen durumlara reaksiyon gösteremeyebilir. Örneğin; Beklenmeyen taleplere cevap verilemeyebilir ve stok bulundurmama maliyetleri söz konusu olabilir. Bu sebeple işletmelerin, özellikle talebin dalgalanan yapıda olduğu durumlarda, ani olarak oluşan talebi karşılayacak miktarda stoğun bulundurması gerekir. (Çevik, 2012)

Literatürde stok yönetimi ile ilgili problemlere bakıldığında; stok problemleri en temel ifade ile işletmelerin sipariş vermesi gereken stoklanacak maddelerin zamanını ve miktarını tam olarak belirleyememesinden kaynaklanmaktadır. "Ancak stok yönetimi ile ilgili problemler talepteki belirsizlikler, üretim süreçlerindeki çeşitlilikler, tedarik zincirindeki birimler arasındaki sevkiyat sürelerindeki değişilikler ve aksamalar nedeniyle oldukça karmaşık hale gelebilmektedir. İ̧̧letmeler tüm bu karmaşık problemleri çözebilmek maksadıyla; farklı tedarik zinciri yapıları ve stok modelleri için optimum çözümü gerektiren matematiksel modeller geliştirmiş olsada, stok modellerinin gerçek hayata yakınlığı arttıkça ve karmaşıklığı arttıkça matematiksel modellerin de karmaşıkığı aynı oranda artmakta ve anlaşıması güçleşmektedir" (Sezen. 2004).

Mali açıdan problem yaşayan işletmelerin problemlerinin nedeni araştırıldığında, üretim birimleri arasında nakit ihtiyacını karşılayacak miktarda gereğinden fazla stok bulundurduğu görülmektedir. Bazı işletmelerde ise, yeterli miktarda hammadde stoğu bulundurduğu, halde birkaç küçük parçanın stokta bulunmamasında dolayı üretimi aksatabilmektedir. Stok yönetiminde bu ve benzeri problemlerin önlenmesi, öncelikle iyi bir planlama, kontrol, üretim ve satış olmak üzere etkili bir stok kontrol sisteminin oluşturulmasıyla önlenebilir.

İşletmeler etkili bir stok kontrol sistemi oluşturmak için; öncelikle malzeme ihtiyaç planlarını oluşturmalıdır. Malzeme ihtiyaç planlarının belirlenmesini müteakip stoklanacak malzeme cinslerine karar verilmelidir. Üretimin sürekli bir faaliyet olduğu göz önünde bulundurulduğunda, sürekliliği sağlamak maksadıyla, sipariş verme zamanı ve elde bulundurulması gereken minimum stok miktarı belirlenmelidir. Stok kayıt işlemleri düzenli olarak takip edilmelidir. Elde tutulan stoklara ayrılacak minimum maliyet hesaplanmalıdır. Ayrıca elde tutulan stokları zaman ve işgücü kaybı yaşamadan uygun şekilde depolanması sağlanmalıdır. (Günay, 2005)

Etkili bir stok kontrol sisteminin işletme ekonomisine sağlayacağı faydalar şu şekilde sıralanabilir; üretimde insan, makine ve malzeme gücünün en etkin şekilde kullanılmasını sağlar. Üretimde aşamasında kullanılacak malzeme ve parçaların bulunamaması sebebiyle oluşan bekleme süreleri ve tedarik zinciri içinde yer alan diğer birimlerin ihtiyaç duyduğu bilgilere kolayca ulaşılabilir. Kaybedilen malzeme ve mamul miktarı azalır, düzeltme için müdahale edilir. Stok kontrol sistemlerinin faydalarına bakıldığında, doğru ve etkin olarak oluşturulan stok konrol sisteminin işletmenin faaliyetlerine artı değer kazandıran en önemli etkenlerden biri olduğu görülmektedir

\subsubsection{Stok Kontrol Sistemleri}

Stok yönetiminde, stokun ihtiyaç duyulduğu zaman tedarik edilmesi ve aynı zamanda stokların elde tutma maliyetlerinin artmaması sağlanmalıdır. İşletmelerin bu durumu sağlayabilmesi için, toplam maliyeti minimum yapacak şekilde her bir üründen ne zaman ve ne kadar sipariş vereceğini belirlemesi gerekmektedir. İşletmeler için oldukça karmaşık gözüken bu soruları yanıtlamak için çeşitli stok kontrol yöntemleri ve modelleri ortaya çıkmıştır. Talep değişkeni, stok kontrol modellerinin sınıflandırmasında temel belirleyicidir. Talep türüne göre; stok kontrol modelleri, olasılıklı modeller ve deterministik ve olarak ikiye ayrılmaktadır.(Sulak, 2008)

İsletmeler tarafından talep miktarının net olarak bilindiği durumlarda deterministik modeller, talebin olasılıksız diğer bir deyişle bağımsız olduğu durumlarda, olasılıklı modeller uygulanmaktadır. Stok yöntemi; stok kaleminin miktarı, değeri, stokta kaldığı sürenin uzunluğu, stok bulundurma maliyeti gibi faktörlerin iyi anlaşılmasını gerektirir. (Ertuğrul ve Tanrıverdi, 2013)

Her işletme büyüklüğü, yönetim ve organizasyon durumu, üretim tipi ve mali durumu gibi birçok faktörü göz önünde bulundurarak işletme yapısına uygun bir stok kontrol sistemi oluşturur. İşletme tipine uygun stok kontrol sistemlerinin oluşturulmasında talebin ayırt edici bir özelliği vardır. Bu kapsamda yaygın olarak kullanılan stok kontrol sistemleri şunlardır: gözle kontrol yöntemi tek kutu yöntemi, , çift kutu yöntemi, ABC yöntemi maksimum-minimum yöntemidir..

Gözle kontrol yöntemi; deneyimli bir depo sorumlusunun belli sürelerde stokları kontrol etmesi ve azalan stok kalemleri için sipariş vermesidir. Ekonomik ve basit bir kontrol yöntemidir. Ancak, deneyimli personel gerektirdiğinden ve küçük işletmeler tarafından kullanabileceğinden kullanım alanları sınırlıdır. Perakende satış mağazaları ve küçük üretim işletmeleri gibi yerlerde yaygın olarak kullanılan bir yöntemdir. Stok kontrolü tamamen görevli personelin inisiyatifine bırakıldığından, talep ve tedarik süresindeki ani değişimler karşısında hata yapma olasılığı yüksek olabileceği göz önünde bulundurulmalıdır. (Kobu, 2014)

Tek kutu yöntemi; kutu olarak nitelenen raf veya yer belli aralıklarla kontrol edilmekte ve doldurulmaktadır. Bu yöntemde stok giriş ve çıkışı için herhangi bir kayıt yapılmamakta, kutu veya raflar periyodik olarak aldığı kadar stokla doldurulmaktadır. Bu 
yöntemde stoksuzluğa düşme ihtimali çok yüksektir ve gözle kontrol yöntemi gibi uygulaması basit ve ucuzdur. (Schroeder, 1993).

Çift kutu yöntemi ile stok kontrolünde depodaki her malzeme iki farklı kutuda tutulur. Büyük kutu boşalıncaya kadar malzeme kullanıır. Büyük kutunun yakınında, malzeme siparişi için bir talep formu vardır. Yenileme talebi gönderilir ve bu esnada küçük kutudaki malzemeler kullanılır. Küçük kutuda, yeni malzeme siparişi teslim alınana kadar yetecek miktarda emniyet stoku vardır. Stok yenilenmek istendiğinde, talep formu tekrar büyük kutunun altına konur, her iki kutu doldurulur ve döngü tekrar başlar. Bu metotla stok kontrolü basittir ve her stok kullanımında kayıt tutmaya lüzum yoktur. Ancak, standart bir çift kutu sistemi olmaması ve malzemelerin herhangi bir uyarı yapılamadan kullanılamaz hale gelmesi veya demode olması ihtimali vardır. (Doğruer, 2005)

$A B C$ yöntemi; ile stoklar kendi içinde gruplandırılır ve bu şekilde kontrol edilir. Bu gruplandırma stokların değerine göre yapılmaktadır. Yüksek değerde olan ürünler en önemli olarak belirlenip daha çok kontrol edilirken, değeri daha düşük ürünler daha az önem arz etmektedir. Ürünleri bu şekilde gruplandırma yaparak kontrol etmek, işletmelere hem zamandan hem maliyetten tasarruf etmelerini sağlar. $A B C$ yöntemi ile, işletmelerin birçok çeşit ve ebatta, değişik önem derecesinde mallardan oluşan stok kalemlerinin toplam içindeki kümülatif yüzdelerine oranlarına göre sınıflandırılmasından ibarettir. Stoklar, stok değerine göre $A, B$ ve $C$ biçiminde üç grupta toplanmaktadır:

Maksimum-minimum stok kontrol yöntemi; bazı durumlarda sabit sipariş döneminde belli aralıklarla sipariş verilmesi nedeniyle sipariş miktarı çok az olabilmektedir. Bu durumu önlemek için uygulanan maksimum-minimum sisteminde sabit sipariş dönemi sistemi ve sabit sipariş miktarı sistemi birleştirilebilmektedir. Aynı zamanda $(S, s)$ sistem olarak da adlandırılan bu sistemde arzu edilen maksimum stok seviyesi (S) ile minimum stok seviyesi (s) belirlenmektedir. Stoklar belirli zaman aralıklarında, gözden geçirilmekte ve stok miktarı önceden belirlenen stok seviyesinin altında ise sipariş verilmektedir. Eğer stok miktarı belirlenen stok seviyesinin altında değilse eldeki stok miktarının bir sonraki döneme yeteceği değerlendirildiğinden sipariş verilmemektedir. (Dilworth, 1993). Bahsi geçen stok kontrol yöntemleri ve temel özellikleri Tablo 1'de belirtilmiştir.

Tablo 1: Stok Sistemleri ve Temel Özellikleri

\begin{tabular}{ll}
\hline Stok Sistemleri & Temel Özellikleri \\
\hline \multirow{2}{*}{ Gözle Kontrol Yöntemi } & Ekonomik ve basit \\
& Deneyimli personel ihtiyacı \\
\hline \multirow{2}{*}{ Tek Kutu Yöntemi } & Basit ve ekonomik \\
\hline \multirow{2}{*}{ Çift Kutu Yöntemi } & Stoksuzluğa düşme tehlikesi \\
\hline \multirow{2}{*}{ ABC Yöntemi } & Hasit ve kayıt zorunluluğu bulunmaz \\
\hline Maksimum - minimum Stok Kontrol Yöntemi & Seviye belirleme ile kontrol \\
\hline
\end{tabular}

Not: (Doğruer, 2005), (Schroeder, 1993), (Kobu, 2014)'ten yazarlar tarafından uyarlanmıştır.

Bahsedilen geleneksel stok kontrol sistemlerinin yanı sıra günümüze daha yakın ve modern olarak nitelendirilen bilgisayarlı kontrol yöntemi de kullanılmaktadır. Bu yöntem ile; işletmelerde bilgisayar kullanımı durumunda stok kontrolü çok daha güvenli ve hızı bir şekilde yapılmaktadır. Bilgisayarda malzeme çıkışına ait bilgiler işlenirken, belirlenen stok seviyesinin altına düşen malzeme de otomatik olarak ayrılır. Bu duruma bağı olarak, eksik miktarları gösteren bir liste hazırlanır ve gerekli siparişler verilmek üzere satın alma servisine gönderilir. Bu bilgiler sayesinde stok seviyeleri kolayca belirlenir. Özellikle barkod (çizgili kod) teknolojisine uygun bilgisayar sistemlerine sahip büyük işletmelerde mal sayımı, malzeme giriş çıkı̧ vb. durumlarda problem yaşanmamaktadır. (Kaya,2004)

\subsection{Depo Sayım Sisteminin Stok Kontrolüne Etkileri}

Depolarda saha operasyonlarına bakıldı̆ı̆nda depo yönetim sistemlerinin birçoğu stok kontrol sistemleri ile entegre değilir. Ancak, lojistik yönetimi süreçlerini bir zincir olarak düşünürsek, bu zincirin halkalarından birini depo yönetim sistemleri, diğer zinciri ise stok kontrol sistemleri oluşturmaktadır. Verilen örnekten de anlaşılacağı üzere depo yönetim süreçleri ve stok kontrol süreçleri birbirinden bağımsız düşünülemez.

Depo yönetim sistemlerinin stok kontrol sistemleri ile entegre olmaması işletmelere ilave maliyet ve zaman yaratmaktadır. Ayrıca depolarda manuel olarak yapılan sayımlar çalışan personel açısından ilave iş yükü ve iş güvenliğini olumsuz etkileyen bir unsur olarak görülmekedir. Endüstri 4.0 destekli stok kontrol modellerinin, depo yönetim sistemleri ile entegre olması halinde 
lojistik süreçlerin daha hızlı ve tutarlı bir şekilde yürütülmesi tahmin edilmektedir. Makalenin sonuç bölümünde geliştirilecek stok kontrol sistemlerinin depo yönetim süreçlerini nasıl etkileyeceği detaylı bir şekilde açıklanmıştır.

\subsection{Endüstri 4.0 Teknolojileri}

Endüstri devriminin gelişim aşamaları incelendiğinde, endüstri 1.0 olarak kabul edilen süreçte; üretimin makinelerle yapıldığını, endüstri 2.0 sürecinde; artan ihtiyaçlardan dolayı seri üretime geçildiği, endüstri 3.0 sürecinde ise dijital teknolojilerin kullanıldığını görmekteyiz. Bu süreçleri kısaca, insan gücünden, makine gücüne geçiş olarak da tanımayabiliriz. (Ekonomik Forum Dergisi Sayı, 2016). Endüstri 4.0 sürecinin başlamasıyla birlikte sadece makine gücü değil, üretim teknolojisinin gelişmesinde etkili bir rol oynayan internetin de kullanılarak üretim safhaları dijitalleşmeye başlamıştır. Bütün bu gelişmelerin, daha önce mümkün olmayan yeniliklere imkân tanımasının yanı sıra, siber- fiziksel sistemler, Nesnelerin ve Hizmetlerin İnterneti gibi faktörlerin de etkisiyle, içinde bulunduğumuz Dördüncü Endüstri Devrimi başladı. (Geliş ve Ersoy, 2018)

Günümüzde modern üretim özellikle Avrupa ülkelerinde önemli bir rol oynamaktadır. Son yıllarda Avrupa ülkeleri endüstrileri yaşlanan nüfus ve gelişmekte olan ülkelerden gelen rekabet gibi birçok problemle karşı karşıyadır. Ekonomik Politika Komitesi ve Avrupa Komisyonu'na göre, çalışma çağındaki nüfus yaklaşık 48 milyon (\% 16) azalacak ve 2050 yılına kadar 58 milyon yaşlı insan olacaktır. 2011'de, gelişmekte olan ülkelerin (Çin, Hindistan ve Brezilya gibi) sanayi değeri payı, 1990'da \% 179 artmıştır. Buna karşılık, Batı Avrupa ülkelerinde endüstriyel değer payı; Almanya, Fransa, Birleşik Krallık olmak üzere toplamda \% 36 oranında azalmıştır. Bu sorunlar, iş gücünün azaltılması, ürün geliştirme süresinin kısaltılması, kaynakların verimli bir şekilde kullanılması, siber fiziksel sistem (CPS) ve nesnelerin interneti (IoT) gibi endüstri teknolojilerinin geliştirilmesini sağlamıştır. Bu teknolojilerin geliştirilmesiyle, dördüncü endüstriyel devrimin başlangıcını simgeleyen 2011 yılındaki Hannover Fuarı etkinliği sırasında Almanlar tarafından yeni bir konsept olan endüstri 4.0 tanıtılmıştır. Illk yayınlanmasından bu yana birçok Avrupa üretim araştırma organizasyonu ve şirketi, endüstri 4.0 altında imalatın bilgi takas eden ve kontrollü makineler ile birlikte çalışabilen özerk ve akıllıca hareket eden üretim birimlerinden oluşacağını vurgulayan bir çalışma hazırlamıştır. (Qina vd. , 2016)

Teknolojinin hızla ilerlemesi ile ürünlerin üretim aşamaları değişmeye başlamıştır. Bu değişime bağı olarak akıllı ürünlerin müşteri ihtiyaçlarına göre planlanması sağlanmış ve bu durum endüstri alanında rekabetle birlikte ürünlerin yaşam döngülerinin kısa zamanda tamamlanmasını da beraberinde getirmiştir. Bu karmaşık düzen, üretimde yer alan ana unsurlarla internet, mobil cihaz, sensörler ve diğer akıllı cihazları birleştirme fikrini ortaya çıkarmıştır. Bu fikir neticesinde endüstri 4.0 kavramı ortaya çıkmıştır. (Bozkurt ve Durdu, 2016)

Ayrıca günümüzde mevcut üretim paradigması sürdürülebilir değildir. Bir taraftan endüstriyel üretim, küresel iklim ısınması ve çevre kirliliği gibi çevresel bozulmaların çoğuna neden olmakta, öte yandan petrol ve kömür gibi yenilenemez kaynaklardan çok fazla tüketilmektedir. Buna ek olarak, nüfusun yaşlanmasından ötürü işgücü arzı azalmaktadır. Bu nedenle, endüstrinin radikal bir değişime ihtiyacı vardır ve bu değişikliği Endüstri 4.0 ele almaktadır. (Wang vd., 2015)

Endüstri 4.0'ın ana bileşenlerinden biri olarak gelecekteki fabrika, sadece sensörler, aktuatörler, makineler, robotlar, konveyörler gibi bütün imalat kaynaklarıyla bağlantılı olan ve otomatik olarak bilgi alışverişi yapan değil, aynı zamanda üretim sürecini kontrol etmek ve fabrika sistemini yönetmek için bilinçli ve akıllı olacaktır. Buna ek olarak üretim süreci; ürün tasarımı, servisler, üretim planlaması ve mühendisliği gibi pek çok alanda modüler olarak benzerini yapacak ve uçtan uca birbirine bağlanacaktır. Bu sebeple, bu süreçlerin sadece merkezi olmayan bir sistem tarafından komuta edilmesi değil, aynı zamanda bağımlı olarak kontrol edilmesi demektir. Geleceğin bu tür fabrikaları Akıllı Fabrika olarak bilinir. (Qina vd., 2016.)

Sabun tesisi, herhangi bir sayıda kişiselleştirilmiş renkli sıvı sabun şişesi üreten akıllı fabrikaların ilk gösterimidir. Müşteriler herhangi bir sayıda farklı sıvı sabun renkleri seçebilirler ve bu üretim tesisi insan kontrolü olmaksızın sabunu üretebilir. Bu üretim tesisi, merkezi olmayan sistemler tarafından kontrol edilen çeşitli iletişim sistemlerinin bir entegrasyonu olarak tasarlanmıştır. (Zuehlke, 2010)

Bu sanayi devriminin ana fikrinde işletmelerde üretim sistemleri bilgisayar, makine, sensör ve birbirine entegre diğer sistemler üzerine kurulacak ve bu sistemler birbiri ile bilgi alışverişinde bulunarak, insanlardan bağımsız olarak kendilerini koordine edip karar verebileceklerdir. Bu sayede maliyetler, üretim süresi, ihtiyaç duyulan enerji miktarı azalırken; üretim miktarı ve kalitesi artacaktır. Günümüzdeki uygulamalardan uzak olarak yeni sistemlerde, üretilen ürünler benzersiz bir seri numarasına diğer bir deyişle bir kimliğe sahip olacak, bu kimlik sayesinde birtakım bilgileri belleklerinde tutacaklardır. (Ege,2014).

Ürünlere tanımlanan kimlik, RFID teknolojileri sayesinde okunur veya takibi yapılabilir. İngilizce isminin kısaltması olarak bilinen “RFID” Türkçe karşılığı olarak Radyo Frekansı ile Tanımlama olarak adlandırılır. RFID’nin yapısında bulunan bileşenler radyo frekansı ile haberleşmektedir. Okuyucu, etiket ve anten RFID'nin 3 temel parçasıdır. Okuyucuların görevi; ürünlere yerleştirilmiş etiketler yardımıyla ürüne ait bilgileri okumak ve radyo dalgaları vasıtasıyla sayısal bir kod şeklinde almaktır. Etiketlerin görevi, bilgileri saklamaktır. Okuyucu ve etiket arasındaki iletişim antenler vasıtasıyla gerçekleşir ve bu olay bağlama olarak adlandırılır. Okuma mesafesi ekstra antenler ile genişletilebilir.(Maraşlı ve Çıbuk, 2015) 
RFID sistemlerinde insan faktörü olmaksızın bilginin oluşturulması ve toplanması amaçlanır. Tüm işletmeler takip etmek istedikleri araba, ürün, taşıyıcı, insan vb. nesneleri uygun nesnelerle eşleştirerek üzerine bilgilerini kaydedebilir ve bu bilgiler belirli mesafelerde okunabilir.

RFID tanımlama sistemleri, Otomatik Tanıma ve Veri Toplama (OT/VT) sektöründe yaygınlaşmıştır. Bu durum tedarik zincirindeki tüm faaliyetlerde malzeme bilgilerinin otomatik olarak okunması ve kaydedilmesini hedeflemektedir. Başta ABD olmak üzere tüm dünyada, RFID sistemlerden Pasif RF sistemleri etiket maliyetlerinin düşmesi nedeniyle ülkemizde de yaygın olarak kullanılmaya başlamıştır. (Çiftçibaşı, 2009)

Endüstri 4.0; çeşitli şirketler, fabrikalar, tedarikçi, lojistik, kaynaklar, müşteriler vb. arasında var olacak tam bir iletişim ağı anlamına gelir. Her bölüm, ağdaki ilgili bölümlerin talep ve durumlarına bağı olarak gerçek zamanlı olarak yapılandırmalarını optimize eder. Buna ek olarak, maliyetler ve kirlilik, hammaddeler, CO2 emisyonları, vs. azaltılacaktır. Yani, gelecekteki iş ağı, kendiliğinden organize bir statüye ulaşabilen ve gerçek zamanlı cevapları iletebilen her bir işbirliği bölümü tarafından etkilenen bir yapıda olacaktır. (Qina vd. , 2016)

Ayrıca, endüstri 4.0 teknolojilerinin fabrikalar, tedarikçi, lojistik vb. alanlarında kullanılmasıyla, iş süreçlerinde yaşanan problemler anlık olarak çözülebilecektir. Böylece çalışan personel için zaman ve emek tasarrufu da sağlanabilecektir.

Akıllı ürünlerin üretiminde; endüstri 4.0 teknolojilerinden yararlanılacak ve sonuçta yeni bir ürün türü oluşturulacaktır. Oluşturulan bu ürünler; bilgi taşıyan işlemci, tanımlanabilir bileşenler ve gömülü detektörler sayesinde üretim süreçlerinde ve üretim sonrası süreçlerde de izlenilebilecektir. Bu sayede; ürünlerden geri bildirim alınabilecektir. Üretim sürecinin nihai sonucu olarak, ürün kalitesinin geriye doğru akıl yürütme algoritmaları aracılığıyla makine koşulları hakkında daha fazla bilgi sağlanabilir. Günümüzde, böyle bir geribildirim döngüsü mevcut değildir ve daha fazla araştırmaya ihtiyaç duymaktadır. (Lee vd. ,2014)

Ayrıca müşteriler açısından fonksiyonel rehberlik sağlama gibi faydaları da söz konusu olabilir. Akıllı ürünlere tanımlanacak olan kimlikler sayesinde kullanıcı durumlarının ölçülmesi ve buna bağlı olarak ürüne oluşacak talebin de ölçülmesi, ürün yaşamının izlenmesi gibi birçok fonksiyon mümkün olabilir.

Ürünlerin akıllı olarak üretilmesi müşterilere birçok avantaj sağlayacaktır. Belki de gelecekte tamamen akıllı bir üretime geçilmesiyle yeni bir satın alma modeli ortaya çıkacaktır. Müşteriler siparişlerini verdikten sonra üretimin herhangi bir aşamasında, siparişlerini değiştirebilecek veya ürüne ilave özellikler ekleyip, çıkarabilecektir. Bu durum birçok faydayı da beraberinde getirecektir. Özellikle; müşteriler ürünün üretim bilgisine de sahip olabileceklerdir. Müşterin yaptığı değişiklikler sayesinde üreticiler ürünlerin kullanım tavsiyeleri hakkında bilgi sahibi olacaktır. En önemlisi; üreticiler yüzde yüze yakın bir müşteri memnuniyeti sağlayabilecektir.

Endüstri 4.0 ile birlikte birçok teknoloji gündeme gelmiştir. Günümüzde bu teknolojilerin sadece birkaçı imalat sanayisinde kullanılmaktadır. Endüstri 4.0 ile birlikte anılan teknolojiler;

a. Siber Fiziksel Sistemler: siber alan, internet ve fiziksel dünyayı birbirine bağlayan sistemler siber-fiziksel sistemler olarak adlandırılmaktadır. Sahip olduğu sensörler vasıtasıyla bu sistemler fiziksel ortamdaki hareketleri internet ortamına aktarmakta ve genel olarak nesnelerin etkileşimini içermektedir. (Geisberger ve Broy, 2012) Üretim sistemlerinde, endüstri 4.0 ve siberfiziksel sistemlerin başarılı entegrasyonu önemli fayda sağlayacaktır. Siber fiziksel sistemler ile elde edilen kazanımlar akıllı fabrikalarda görülmektedir. Akıllı fabrikaların ortaya çıkması, internetin insanların bilgi ile etkileşime girme şeklini değiştirdiği gibi, mühendislik sistemlerinin etkileşimini de değiştirmesi beklenmektedir.

Siber fiziksel sistemler ile her fiziksel bileşen ve makine, siber uzayda, sensör ağlarından ve manuel girişlerden üretilen verilerden oluşan ikiz bir modele sahip olacaktır. Akıllı algoritmalar verileri siber uzayda işleyecek, böylece fiziksel bileşenlerin sağlık koşulları, performansı ve riskleri hakkındaki bilgileri gerçek zamanlı olarak hesaplanacak ve senkronize edilecektir. Bu ortamda üretim sistemi aynı zamanda bireysel makineler için performanslarına göre özelleştirilmiş imalat kriterleri de programlayabilir. Sonuç olarak, üretim sistemi, her bir ürünün üretimini, yüksek bir garanti sağlamak için üretim hattında yer alan tüm makinelerin mevcut durumuna göre kişiselleştirecek şekilde konfigüre edebilir. Optimum işletme maliyetleri ile kaliteli üretim böylesine akıllı bir fabrikada imalatçı, üretimdeki son dakika değişikliklerini ve geleneksel fabrikalarda elde edilemeyen diğer esneklikleri destekleyerek müşteri şartnamesini karşılayabilmektedir. (Lee, 2015)

b. Öğrenen Robotlar: Robotik sistemlere altyapı oluşturacak birçok çalışma daha önceki süreçlerde yapılmıştır. Bu çalışmalara, ElCezeri tarafından 1100 'lü yıllarda gerçekleşen robotik sistemler örnek verilebilir. Fakat bugünkü anlamıyla robot kelimesi ilk kez 1920 yılında yazılan "Rossum's Universal Robots" adlı oyunda yer almaktadır. 1940'lı yıllardan sonra endüstriyel robotların farklı çeşitleri geliştirilmiş ve endüstri alanında kullanılmıştır. Otomatik olarak iş yapma yeteneği olan makineler olarak kabul edilen robotlar, hâlihazırda endüstri alanında önemli bir yere sahiptir. Robotik sistemler ile birlikte John McCarthy 1956 yılında Yapay Zeka'yı (Artificial Intelligence) bir bilim olarak tanımlamıştır. John McCarthy'nın tanımına göre yapay zeka ile akıllı 
makineler yapılabilir. Bu tanımın ilk örneği; 1966 yılında geliştirilen, algılama ve algılar sayesinde karar vererek hareket eden SHAKEY adlı gezgin robottur. Üçüncü nesil robotlar ise 1980 yılında çevresindeki olayları algılamasının yanı sıra algılarına bağlı olarak bir plan üreten ve bu plana uygun davranan olarak tanımlanmaktadır. Bu tanım otonom robot tanımının da temelini oluşturmaktadır. Ancak yine de 90'lı yıllara kadar robotik alanındaki uygulamalar endüstriyel robotlardır. (Yazıcı, 2016)

Robotlar daha fazla yarar sağlamak için her geçen gün gelişmekte ve daha özerk, esnek ve kooperatif haline gelmektedirler. Endüstri 4.0 ile, bu robotlar bugün daha az maliyetle üretilecek ve üretimde kullanılanlardan daha geniş bir yetenek yelpazesine sahip olacaklar. Örneğin, Avrupalı bir robot üreticisi olan Kuka, birbirleriyle etkileşime giren özerk robotlar sunmaktadır. Bu robotlar birbirlerine entegre şekildedir, böylece birlikte çalışabilir ve eylemlerini kendilerini bekleyen bir ürüne göre otomatik olarak ayarlayabilirler. Kontrol üniteleri ve üst düzey sensörleri, insanlarla yakın çalışma olanağı sağlayabilir. (Rüßmann vd. , 2015)

c. Nesnelerin interneti kavramı; illk kez 2011 yılında Kopetz tarafından bir işletmede bulunan farklı kaynaklardan verilerin toplanılabilmesi, çoğaltılabilmesi ve organize edilebilmesini anlatmaktadır. Nesnelerin İnterneti, süreç kontrollerini hızlandırmakta ve bağlantısız bir veri yönetimi sağlamaktadır. Bu teknoloji, büyük veri kullanılarak bu verinin siber-fiziksel sistemi harekete geçirebilecek bilgiye dönüştürülmesinde kullanılır. (Lee vd.,2015)

Günümüzde sadece bir üretici sensörlerinin ve makinelerinin bir kısmı ağa bağlanmış ve gömülü bilgi işlem uygulamalarını kullanmaktadır. Bunlar genellikle, sınırlı bilgi ve otomasyon denetleyicilerine sahip sensörlerin ve alan aygıtlarının üzerinde bulunan bir üretim-işlem kontrol sistemine girdiği dikey bir otomasyon piramidinde düzenlenir. Ancak nesnelerin interneti ile, bazen tamamlanmamış ürünler de dahil olmak üzere daha fazla cihaz gömülü bilgi işlem ile zenginleştirilecek ve standart teknolojiler kullanılarak bağlanacaktır. Bu, alan aygıtlarının birbirleriyle iletişim kurmasına ve birbirleriyle etkileşime girmesine ve gerekirse daha merkezi denetleyicilerle etkileşime girmesine izin verecektir. Aynı zamanda analitik ve karar vermeyi merkezîleştirir ve gerçek zamanlı yanıtlar sağlamaktadır.(Rüßmann vd. , 2015)

Nesnelerin interneti kavramının, endüstri alanındaki karşılığı nesnelerin endüstriyel interneti olarak karşımıza çıkmaktadır. Nesnelerin endüstriyel interneti, büyük veri teknolojisi içerisinde, makineden makineye (M2M) bilgi akışını ve endüstriyel otomasyon teknolojilerini kullanmayı içerir. Bu kapsamda, akıllı cihazların insanlardan daha verimli olarak verileri doğru bir şekilde, birbirleriyle tutarlı ilettiklerini düşünmek mümkündür. Makineler arasındaki bu bilgi akışı, şirketlerin kaynaklarını güvende tutmalarını ve iş zekâsı çalışmalarını desteklemelerini sağlayabilir. Nesnelerin endüstriyel interneti, özellikle üretim ortamında kalite kontrol, faaliyetlerin devamlılığı, tedarik zincirinin izlenebilirliği ve verimliliği açısından önemlidir.

ç. Bulut Bilişim: Bulut bilişim 1950'li yıllarda ortaya çıkmıştır. 2006 yılında Amazon, veri merkezlerini modern hale getirerek bulut bilişimin gelişmesine önemli katkı sağlamış ve bulut bilişim hizmeti olarak adlandıılan Amazon S3'ü hizmete geçirmiştir. Gartner (Danışmanlık ve Araştırma Şirketi) ise 2008'li yıllarda bulut bilişimi; bilgi teknoloji hizmetleri sektöründe kullanıcılar ve tedarikçiler arasındaki ilişkiyi değiştirebilecek bir potansiyel olarak nitelendirmiştir. (Bulut, 2018)

Bulut teknolojisinde ortaya çıkan yeni gelişmeler, Enformasyon Teknolojileri (IT) üreticileri ve bunların tüketicilerinin düşünce biçimini etkilemiştir. Bulut bilişim sistemleri, iş modellerinin temel yapısı, yazılımı ve internet servisleri konusunda köklü değişiklere neden olmuştur. (Wang vd., 2015) Bulut bilişim sistemleri birçok kuruluş tarafından kurulur ve paylaşılır. Bulut sunucusu tarafından sağlanan bu teknoloji kişisel bilgisayarların yükünü azaltmak amacıyla kullanılır. Bulut teknolojileri sayesinde kullanıcıların, bilgisayarlarına indirmek ve yüklemek istemedikleri uygulamalar depolanabilir. Bu sayede, internete bağlanan cihaz ile her yerde bu bilgilere, programlara ve verilere kolaylıkla ulaşım sağlanabilir.

Bulut teknolojileri ile birlikte kullanılacak olan robotlar büyük bir işlem gücü gerektirir. Bulut sistemi, işlem gücüne ve depolamaya kolay erişim imkânı sağlar. Gelecekte robot üreticileri, nesnelerin interneti kavramının da gelişmesiyle operasyonel destek ve veri merkezi alanları gerektiren robotlar üretmek yerine bulut bağlantılı robotlar üreteceklerdir. Yeni bir döneme hızla geçiş yaptığımız bu süreçte robotların da beraberinde getirdiği siber güvenlik sorunu dikkate alınmalıdır.(Kahraman, 2018)

d. Büyük Veri Analitiği: Büyük veri setlerine dayanan analiz, üretim kalitesini optimize eden, enerji tasarrufu sağlayan ve ekipman servisini geliştiren imalat dünyasında kısa süre önce ortaya çıkmıştır. (Rüßmann vd. , 2015) Büyük veri analitiği kavramı 2000'li yıllarda endüstri analisti Doug Laney' ın, "Büyük Veri"yi 3V olarak tanımlamasıyla büyük bir kazanmıştır. 3V; İngilizce volume (hacim), velocity (hız) ve variety (çeşitlilik) kelimelerinin bir araya getirilmesiyle oluşmaktadır.(Eğer, 2018) Büyük veri genel olarak; programların saklama, yönetme ve işleme kapasitesinden ziyade veri kümelerini anlatmak için kullanılan bir terimdir.

Büyük verinin, boyutları ile analizlerin karmaşıklığının birleşmesi, yeni teknolojilerin ve bunları yönetecek araçların gelişmesine neden olmuştur. Aslında büyük veri, yönetilen verinin türünü ve onu depolamak için kullanılan teknolojiyi açıklamaktadır. Bu teknolojiler; Google, Amazon, Facebook ve Linkedln vb. şirketlerin büyük sosyal medya verileri sayesinde, kendileri için geliştirdikleri teknolojiden doğmuştur. (Cackett, 2013) 
Büyük veriler gelecekte önemli değerler sağlayacaktır. Büyük verilerin kullanımı artık ölçeklenebilir bir depolama ve bilgi işlem yeteneği sağlayan bulut bilgi işlemi ile mümkün olacaktır. Hangi verilerin toplanacağı, bu verilerin nasıl toplanacağı, nasıl formüle edileceği, anlamının ne olduğu ve nasıl analiz edileceği hakkındaki soruların öncelikle yanıtlanması gerekmektedir. Çeşitli verileri toplamak ve bunları nasıl kullanacağını düşünmek yerine, pratik başlangıcın hangi bilgilerin kalite ve verimlilikle ilgili faktörleri ortaya çıkarabileceği göz önünde bulundurulmalıdır. Örneğin, arıza makineleri, ürün kalitesini ve bitmiş ürün oranını düşüreceğinden, insanların önceden cevap verebilmesi için sorunları öngörmek için makine durumu ve çalışma geçmişi izlenmeli ve analiz edilmelidir. Verimliliği artırmak için, her işlemin imal (işlem) süresini ve her makinenin çalışma süresinin bilinmelidir. Bu işlemlerdeki performans darboğazını tanımaya ve makinelerin dengesizliğini yüklemeye yardımcı olur. (Wang vd. , 2015)

Endüstri 4.0 bağlamında, üretim sistemlerinden veriler toplanarak, kapsamlı değerlendirme ile gerçek zamanlı karar verme mümkün hale gelebilir. Bu sayede üreticiler, üretim sürecinin sonunda test aşamasında oluşan bir hatayı, üretimin başlayıcındaki süreçler ile ilişkilendirerek üretim sürecinin başlarında hataları belirleyip, ortadan kaldırarak üretim kalitesini artırabilir. Yeni iş modellerinin oluşturulabilmesi için endüstri 4,0’ın çeşitli paradigmalarından bahsedilmiştir. Endüstri 4.0 ile birlikte genel olarak üç boyuttan bahsedilir. Bunlar; değer yaratma ağları arasında yatay entegrasyon, ürün yaşam döngüsünde baştan sona mühendislik, imalat sistemlerinde bağlantı ve dikey entegrasyon.(Wang vd. , 2015 )

Şirketlerin yatay entegrasyonu ve fabrikanın dikey entegrasyonu: Mühendislik sürecinin uçtan uca entegrasyonunun iki temeldir. Bunun nedeni, ürün yaşam döngüsü, farklı şirketler tarafından gerçekleştirilmesi gereken birkaç aşamadan oluşmasıdır. Bir şirket, hem diğer ilgili şirketler ile rekabet etmeli aynı zamanda işbirliği de yapmalıdır. Kurumlar arası yatay entegrasyon sayesinde ilgili şirketler etkili bir çevre oluşturabilirler. Bu şirketler arasında finans, bilgi ve materyal kolaylıkla dolaşabilir. Bu durum, yeni değer ağları ve iş modellerinin ortaya çıkmasına katkı sağlayabilir.(Wang vd., 2015)

Ürün yaşam döngüsünde baştan sona mühendislik: Ürün yaşam döngüsünün tüm aşamalarında ürünün hammaddesinin tedarik edilmesinden, üretilmesi, kullanılması ve tüketilmesinde kadar olan süreçlerde akıllı çapraz bağlantı ve dijitalizasyonu içermektedir. (Alçın, 2016) Ürün odaklı bir değer yaratma sürecinde, müşteri gereksinimi ifadesi, ürün tasarımı ve geliştirme, üretim planlaması, üretim mühendisliği, bakım, servisler ve geri dönüşüm gibi bir dizi faaliyet gerçekleştirilir. Entegrasyon ile sürekli ve tutarlı bir ürün modeli her aşamada yeniden kullanılabilir. Ürün tasarımının üretim ve servis üzerindeki etkisi, güçlü yazılım zincirinin kullanılmasıyla öngörülebilir, böylece özelleştirilmiş ürünler etkinleştirilir.(Wang vd. , 2015)

Dikey entegrasyon ve ağ üretim sistemleri: Üretim merkezinden üretim hücreleri, hatları ve fabrikalar yoluyla bir değer oluşum modellinin, farklı birleştirme ve hiyerarşik seviyelerdeki akıllı çapraz bağlanması ve dijitalleştirilmesi olarak tanımlanır. Ayrıca; pazarlama, satış ve teknoloji geliştirme gibi değer zinciri ile ilgili faaliyetleri de entegre eder.(Stock ve Seliger, 2016) Bir fabrika; aktüatör, sensör, kontrol, üretim yönetimi, imalat ve kurumsal planlama gibi çeşitli fiziksel ve bilgi alt sistemlerine sahiptir. Esnek bir üretim sistemini etkinleştirmekiçin sensör ve aktüatör sinyallerinin farklı seviyelerden kurumsal kaynak planlaması (ERP) seviyesine dikey olarak entegrasyonu için gereklidir. Bu entegrasyonla akıllı makineler üretim sürecini şeffaf hale getirmek için, dinamik olarak farklı ürün türlerine uyum sağlayacak şekilde yeniden yapılandırılabilen ve kendi kendini organize eden bir sistem oluşturur. (Wang vd. , 2015)

e. Katmanlı Üretim: Kahraman (2018) bu kavramı ultraviole ışınlarının protetiplemenmesi ile elde edilerek endüstri haline getirilmesi olarak tanımlamıştır. Sistem katmanlı üretim teknolojileri olarak anılmaya başlayarak parça elde edilmesinde kullanılmıştır.

"Şirketler daha çok, çoğunlukla prototip oluşturmak ve tek tek bileşenler üretmek için kullandıkları 3 boyutlu baskı gibi ek üretim yöntemlerini uygulamaya başlamışlardır. Endüstri 4.0 ile bu toplu üretim yöntemleri, karmaşık ve hafif tasarımlar gibi inşaat avantajları sunan küçük ölçekli özel ürünler üretmek için yaygın bir şekilde kullanılmaktadır. Yüksek performanslı, merkezden bağımsız toplu üretim sistemleri nakliye mesafelerini ve eldeki stokları azaltacaktır. Mühendislik aşamasında, malzemelerin ürünlerin ve üretim işlemlerinin 3 boyutlu simülasyonları zaten kullanılmaktadır ancak gelecekte simülasyonlar kapsamlı şekilde kullanılacaktır. Bu simülasyonlar, gerçek dünyadaki verileri, fiziksel dünyayı, makineler, ürünler ve insanları içerecek şekilde sanal bir modelde yansıtmak için kaldıraç kuvveti uygulayabilecektir. Bu, operatörler fiziksel değişimden önce sanal dünyadaki ürünün makine ayarlarını test ederek optimizasyon sağlamalarını ve böylece makine kurulum sürelerini azaltarak kaliteyi artırmayı amaçlamaktadır. Günümüzde üreticiler, fiziksel makinedeki verileri kullanarak parçaların işlenmesini taklit edebilen bir sanal makine geliştirmişlerdir. Bu durumun, gerçek işleme sürecinin kurulum süresini yüzde 80 'e kadar düşüreceği tahmin edilmektedir." (Rüßmann vd. , 2015)

Öte yandan, üç boyutlu yazıcılar üzerinde iyileştirme ve geliştirme çalışmaları hızla devam ediyor. Örneğin, metal tozlarını kullanıp lazer ile birleştiren özel amaçlı bir üç boyutlu yazıcı ile, bir savaş gemisi çeşitli boyutlarda ve türlerdeki yedek parça ihtiyacı için hiçbir limana uğramadan ve tedarik almadan, gemi içerisinde bulunan üç boyutlu yazıcıyı kullanarak istenilen parçaları istenilen karmaşıklık seviyesinde üretebilir hale gelmiş durumdadır. Benzer şekilde uluslararası uzay istasyonunda gerekli olabilecek bir üç boyutlu parça, uzay istasyonu içerisinde bulunan bir üç boyutlu yazıcıdan elde edilebiliyor. (Yıldız, 2017) 
Katmanlı üretimin endüstri 4.0 çağında önemli bir yere sahip olacağı düşünülmektedir. Katmanlı üretim sayesinde, tasarımda değişiklikler ve üretimi güç olan parçaların kısa sürede kolaylıkla üretilmesi beklenmektedir.

f. Arttırılmış Gerçeklik: Son yıllarda bilişim teknolojileri alanında en çok yer alan teknolojide Artırılmış Gerçeklik (AG) teknolojisidir. Birçok alanda çalışmanın yapıldığı artırılmış gerçeklik, günden güne hayatımıza daha fazla girmeye başlamış bir teknolojidir. Gerçeklik teknolojisi en basit anlamda, artırılmış gerçeklik ve sanal gerçeklik olarak ikiye ayrılabilir. Artırılmış gerçeklik; gerçek dünya ile bağlantısını devam ettiren, veri ve görüntülerin gerçek dünya görüntülerine eklenebildiği, gerçek ve sanal nesnelerin aynı ortamda birlikte algılanmasını sağlamaktadır. Sanal gerçeklik ise; bilgisayar kaynaklı üç boyutlu oyunlarda karşılaşılan, kullanııının bu ortama girdiğinde dünya ile ilişkisinin tamamen yok olduğu bir ortam olarak ifade edilmektedir. (iç̧ten, 2017) Artırılmış gerçeklik tabanlı sistemler, bir ambarda mobil cihazlar ve parça seçimi üzerinden onarım komutları gönderme gibi türde hizmetleri desteklemektedir. Hâlihazırda bu sistemler emekleme aşamasındadır ancak gelecekte şirketler, çalışanlarına karar vermek, çalışma usullerini iyileştirmek, gerçek zamanlı bilgiler sunmak için genişletilmiş gerçeklerden daha fazla yararlanacaklardır. (Rüßmann vd., 2015)

g. Siber Güvenlik: Güvenlik olmaksızın akıllı fabrikalarımıza hizmet etmek pek mümkün görünmemektedir. Akıllı fabrikaların geleneksel internet uygulamalarına göre daha büyük güvenlik sorunlarıyla karşılaşabileceği tahmin edilmektedir. Özellikle müşteriler, tedarikçiler, ticari stratejiler ve teknik bilgiler hakkında bilgilerin korunması işletmeler açısından büyük önem taşımaktadır. Bu tür bilgilerin açığa çıkması bir takım hukuki sonuçlar doğurabileceği gibi büyük bir kâr kaybına da neden olabilir.

Tablo 2: Endüstri 4.0 Teknolojileri ve Uygulama Alanları

\begin{tabular}{ll}
\hline Endüstri 4.0 Teknolojileri & Uygulama Alanları \\
\hline Siber Fiziksel Sistemler & $\begin{array}{l}\text { Fiziksel ortamdaki hareketleri internet ortamına aktarmak ve } \\
\text { genel olarak nesnelerin etkileşimi }\end{array}$ \\
\hline Öğrenen Robotlar & Daha özerk, esnek ve kooperatif robotlar \\
\hline Nesnelerin İnterneti Kavramı & $\begin{array}{l}\text { Büyük veri teknolojisi içerisinde, makineden makineye (M2M) } \\
\text { bilgi akısını ve endüstriyel otomasyon teknolojileri }\end{array}$ \\
\hline Bulut Bilişim & $\begin{array}{l}\text { Robotlar büyük bir işlem gücü gerektirir. Bulut sistemi, işlem } \\
\text { gücüne ve depolamaya kolay erişim }\end{array}$ \\
\hline Büyük Veri Analitiği & $\begin{array}{l}\text { Yönetilen verinin türünü ve onu depolamak için kullanılan } \\
\text { teknoloji }\end{array}$ \\
\hline Katmanlı Üretim & $\begin{array}{l}\text { Ultraviole ışılarının protetiplemenmesi ile elde edilerek } \\
\text { endüstri haline getirilmesi }\end{array}$ \\
\hline Arttırılmış Gerçeklik & \begin{tabular}{l} 
Gerçek ve sanal nesnelerin aynı ortamda birlikte algılanması \\
\hline Siber Güvenlik
\end{tabular} \\
\hline
\end{tabular}

Not: (Boston Consulting Group, 2014)'ten yazarlar tarafindan uyarlanmıştır

Endüstri 4.0 teknolojileri kullanılırken, makineler ve diğer fiziksel nesneler ve hatta insanlar bir buluta bağlıdır. İşletmelerde, güvenlik sorunu yaşandığında, bu nesneler doğrudan mal kaybına neden olacak şekilde çalışabilir. Bu gibi sorunlar yaşamamak için işletmeler tarafından şifreleme ve yetkilendirme sistemleri endüstri 4.0 uygulamalarında kullanılabilir. Ancak bu sistemlerin siber güvenliği tamamen sağlayıp sağlamayacağı değerlendirilmelidir. Akılı fabrika için özel olarak tasarlanmış yeni yazılımlar geliştirilebilir. Birçok şirket hala bağlantısız veya kapalı yönetim ve üretim sistemlerine güvenmektedir. Endüstri 4.0 ile birlikte gelen standart iletişim protokollerinin artan bağlantısı ve kullanımıyla önemli endüstriyel sistemlerin siber güvenlik tehditlerine karşı koruma ihtiyacı çarpıcı bir şekilde artmaktadır. Sonuç olarak, makinelerin ve kullanıcıların karmaşık kimlik ve erişim yönetiminin yanı sıra güvenli, güvenilir iletişim kurulması da önemlidir. (Rüßmann vd., 2015)

\section{VERI VE YÖNTEM}

Araştırmanın amacı, endüstri 4.0 teknolojilerini kullanan işletmelerde uygulanan stok kontrol yöntemlerinin incelenmesidir. Literatüre bakıldığında stok yönetim ve kontrol süreçleri hakkında birçok araştırma mevcuttur. Ancak literatürde, teknolojinin gelişmesine bağlı şekilde yeni bir kavram olarak gündeme gelen Endüstri 4.0 teknolojileri ve bahse konu teknolojilerin stok kontrol sistemlerindeki uygulamaları hakkında yapılan herhangi bir araştırmaya rastlanmamıştır. Bu kapsamda, lojistik işletmelerde uygulanan Endüstri 4.0 destekli stok kontrol sistemlerindeki verimlilik durumunu bu sektördeki uluslararası alanda faaliyet gösteren bir lojistik işletmede incelenmiştir.

Araştırmada İstanbul Bölgesi'nde faaliyet gösteren ve arge merkezi olan tedarik zinciri ile lojistik yönetimi alanında hizmet veren bir şirket seçilmiştir. Yapılan araştırmada, uluslararası alanda tedarik zincir ve lojistik yönetimi yapan söz konusu şirketin 
uygulamaları incelenmiştir. Şirketin tüm dünyada faaliyet göstermesi, birçok arge merkezi olması, sürekli süreç geliştirme ve maliyet düşürme çalışmaları yapması bu şirketin seçilmesinde etkin rol oynamıştır.

Araştırma nitel araştırma yöntemlerinden örnek olay çalışması (case study) ile yapılmıştır. Bu kapsamda çalışmanın ilk bölümlerinde literatür taraması yapılmış, stok kontrol süreçleri, stok kontrol süreçlerindeki problemler, Endüstri 4.0 teknolojilerinin amaçları ve şekilleri incelenmiştir.

Veriler doküman analizi ile birlikte gözlem ve yarı yapılandııılmış görüşmeler yoluyla toplanmıştır. Yapılan literatür taramasında özellikle stok kontrol modelleri ve endüstri 4.0 teknolojilerinin uygulama alanlarına yönelik veriler toplanmıştır. Daha sonra İstanbul ilinde Endüstri 4.0 teknolojilerini uygulayan şirketler araştırılmıştır. Yapılan araştırma neticesinde halihazırda Endüstri 4.0 teknolojilerini uygulayan iki şirket olduğu tespit edilmiştir. Bahse konu şirketlerden biri seçilerek literatür taraması sonucu elde edilen bilgiler ışığında yarı-yapılandırılmış soru formları hazırlanarak görüşme yapılmıştır. Çalışmanın araştırma sorusu olarak “Endüstri 4.0'ın stok kontrolü üzerine olan etkileri” belirlenmiştir.

Veri toplamak için, araştırmacılar endüstri 4.0 kullanmakta olan iki adet lojistik firması ile görüşmüştür. Görüşme yapılan firmalardan biri üçüncü parti lojistik hizmetleri, ikincisi dördüncü parti lojistik hizmetleri sunmaktadır. Yapılan literatür taraması sonucunda stok kontrol modelleri ve endüstri 4.0 teknolojilerinin uygulama alanlarına yönelik olarak veri toplanmıştır. Daha sonra İstanbul ilinde Endüstri 4.0 teknolojilerini uygulayan şirketler araştırılmıştır. Yapılan araştırma neticesinde halihazırda Endüstri 4.0 teknolojilerini uygulayan iki şirket olduğu tespit edilmiştir. Bahse konu şirketlerden biri seçilerek literatür taraması sonucu elde edilen bilgiler ışı̆̆ında yarı yapılandırılmış soru formları hazırlanarak görüşme yapılmıştır.

Endüstri 4.0 teknolojilerini uygulayan İstanbul'da konuşlu bir lojistik şirketten veri toplanmıştır. Lojistik şirketi olağan halinde ele alınmış, gerçekçi ve mantıklı sonuçlar ortaya konmuştur.

Veri toplamak amacıyla yapılan yarı yapılandırılmış görüşme soruları aşağıda belirtilmiştir: (1) Depolarınızda Endüstri 4.0 teknolojilerinden hangilerini kullanıyorsunuz?, (2) Depolarınızda kullandığınız Endüstri 4.0 teknolojilerinin size sağladığı avantajlar nelerdir?, (3) Stok kontrol süreçlerinde Endüstri 4.0 teknolojilerinden hangilerini kullanıyorsunuz?, (4) Stok kontrol süreçlerinde mutlaka kullanılması gereken Endüstri 4.0 teknolojilerinden nelerdir?, (5) Stok kontrol süreçlerinde kullandığınız Endüstri 4.0 teknolojilerini nasıl belirlediniz?

Yarı yapılandırılmış görüşmenin doğal bir sonucu olarak, görüşmeciler yukarıda belirtilen sorular çerçevesinde cevaplar vermiş, görüşmeciler ise aldıkları cevaplara karşılık olarak yukarıda belirtilenden farklı sorular da sorarak ayrıntıları öğrenmeye çalışmışlardır. Her görüşme ortalama bir saat sürerek, görüşme sonrasında deşifre edilmiştir.

\section{BULGULAR VE TARTIŞMA}

İşletmenin halihazırda endüstri 4.0 teknolojilerini kullanarak geliştirdikleri stok kontrol sistemlerini henüz uygulamadığı, ancak endüstri 4.0 teknolojilerini kullanarak geliştirdikleri stok kontrol sistemlerinin proje aşamasında olduğu bilgisine ulaşılmıştır. Bahse konu sistemlerin proje aşamasında olmasından dolayı bazı bilgiler gizli tutulmuştur. Yarı-yapılandırılmış soru formları proje aşamasında olan ve yakın zamanda uygulamaya geçecek stok kontrol sistemleri üzerinden yanıtlanmıştır.

Yapılan görüşme neticesinde depolarda; RFID etiketleri, manlift (insan asansörü) ve sepet kullanılarak stok kontrol süreçleri yürütülmektedir. Depoda manlift (insan asansörü) ve sepet kullanılması tamamen manuel bir uygulamadır. RFID etiketlerinin kullanılması ise insan hatalarının en aza indirilmesi ve daha sık kontrol yapılmasına imkân vermesi gibi özellikleri nedeniyle endüstri 4.0 teknolojilerinin kullanıldığı bir sistem olarak olarak kabul edilmektedir.

Endüstri 4.0 teknolojilerindeki hızlı gelişmeler, özellikle de üretim sistemleri üzerinde yapılan yoğun çalışmalar sonrasında endüstri 4.0 teknolojilerinin işletmelere sağladığı yararların anlaşılması ve uygulamada görülmesi, işletmelerin yeni sistemleri uygulamalarını ve benimsemelerini hızlandırmıştır. Bu sistemlerinin işletmeler tarafından benimsenmesinde; artan rekabet ortamında rekabetçi kalabilme, tedarikçiler ve müşterilerle daha etkin iletişim kurabilme, iş süreçlerini geliştirme, böylece maliyet indirimi ve verimlilik artışı sağlama gibi faktörler etkili olmuştur. Ancak yapılan görüşmeler neticesinde; Endüstri 4.0 teknolojilerinin depo yönetimi sistemlerinde her geçen gün artarak yerini aldığı, ancak stok kontrol sistemlerinde daha çok yeni bir teknoloji olduğu ve yapılan birçok uygulamanın henüz proje aşamasında olduğu görülmüştür. Günümüzde Endüstri 4.0 çağının getirdiği yenilikleri kullanan RFID teknolojisi, birçok farklı birim arasında entegrasyonu sağlayarak, anlık bilgiya ulaşmayı sağlamıştır. Bu kapsamda değerlendirildiğinde; depo girişinde RFID etiketinden ürün bilgilerinin okunması ve okunan bilgilerin depo yönetim sistemine anlık olarak ulaşmasından dolayı Endüstri 4.0 teknolojilerinden yatay ve dikey entegrasyon teknolojisinin kullanıldığını söyleyebiliriz.

Endüstri 4.0 teknolojilerinin depo yönetim sistemlerinde uygulamaya geçmesi ile işletmelerin birçok alanda avantaj elde etmesi beklenmektedir. Bu kapsamda işletmelerin depo yönetim sistemlerinde Endüstri 4.0'ı kullanarak elde edeceği avantajlar sıralandığında otonom robotların kullanılması ile; Makineler stokların durum düzeylerini kontrol etmek için bağımsız ya da insan 
asistanı olarak çalışabilir. Birbirleriyle iletişim halinde olan makine ve robotlar esnek fabrikaların oluşmasını sağlayacaktır. İleri otomasyon, veri ve benzetim teknikleri kullanımı üretim hızını arttıracak ve ihtiyaç duyulan stok miktarlarının azalmasına sebep olacaktır. Simülasyon kullanılması ile Depoda karşılaşılabilecek olumsuzluklar önceden tahmin edilebilecektir. Yatay ve dikey entegrasyonun kullanıması ile; dikey entegrasyonda siber fiziksel sistemlerin kullanımı ile fabrikaların ve üretim sistemlerinin talep seviyelerine, stok durumlarına, arıza/bakım konularına anlık reaksiyon verebilmeleri söz konusu olacaktır. Nesnelerin internetinin kullanılması ile; aynı anda birden fazla birim tarafından stokların depo içindeki yerleri ve miktarları hakkında bilgi sahibi olunabilir.

Siber fiziksel sistemlerin kullanılması ile; ürüne oluşabilecek talep tahminleri yapılabilecektir. İşletmeler, müşterilerini tanıyacak ve müşteri ihtiyaçlarına göre ürün stoklayacaktır. Stok seviyesinde meydana gelen değişikliklere hızlı bir şekilde tepki verilebilecektir. Bulut teknolojisinin kullanılması ile; İ̧̧letmeler, fabrikalar, tedarikçi, lojistik, kaynaklar, müşteriler vb. arasında gerçek zamanlı iletişim sağlayarak, işletmeler tarafından oluşacak talepler üzerine üretim yapacak ve bu durum da stok seviyelerinde düşüşe neden olabilecektir. Eklemeli üretim teknolojisinin kullanılması ile; yüksek performanslı, merkezden bağımsız toplu üretim sistemleri nakliye mesafelerini ve eldeki stokları azaltacaktır. Stok maliyeti minimize edilecektir. Makine durumu ve çalışma geçmişi izlenebilecektir. Artırılmış gerçeklik teknolojisinin kullanılması ile; Stok kontrol süreçlerinde görevli personel değişen stok çeşitlerine daha kolay adapte olacak ve stokların depoda iken muhafazası ve bakımı konularında bilinçli hale gelecektir. Büyük veri analitiğinin kullanılması ile; gerçek zamanlı verilerin analizi sayesinde stok kontrol süreçlerinde meydana gelen bir sorun önceden tespit edilip giderilebilecektir.

Mevcut durumda Endüstri 4.0 çağının getirdikleri teknolojiler ve avantajlar düşünüldüğünde; teknolojiler ve avantajlar sadece depo yönetim sistemlerini değil tedarik zinciri içerinde yer alan tüm lojistik faaliyetleri etkilecektir. Bahse konu durum farklı bir açıdan ele alındığında depo yönetim sistemlerin meydana gelen bir değişiklik hiç şüphesiz sistem içerisinde yer alan tüm birimleri etkileyecektir. Bu etki, yapılan literatür araştırması ve işletmelerle yapılan görüşmeden de anlaşılacağı üzere lojistik faaliyetleri iyilleştiri ve kolaylaştırıcı yönde olacaktır. Depo yönetim sistemlerinde, depo çalışanının yerini robotlar veya kobotlar alacak, insangücü kısmen ya da tamamen ortadan kalkacaktır. Depolarda insan faktörünün kaldırılması ile depo çalışanı sadece fiziksel olarak çalışan bir iş gücü olmaktan çıkacak ve sistemin getirdiği yenilikleri yöneten, beyin gücü ile çalışan bir varlık olarak depoda yerini alacaktır. Bu durum depolarda yaşanan kazaları azaltarak, sistemin daha verimli çalışmasını sağlayacaktır.

Günümüzde tedarik zinciri içinde yer alan stok yöneticilerinin ve firmaların karmaşık stok modellerini uygulamak ve denemek için zamanı yoktur. Ayrıca işletmelerin stokları etkin bir şekilde yönetebilmelerin için çeşitli ekipman ve araç gereçlere de sahip olmalıdır. Drone ile stok kontrolü geliştirilen projeler arasındadır. Drone ile stok kontrolünde görüntü kalitesi ve lokasyon başına düşen sayım süresi önemli parametreler olarak belirkenmiştir. Bahse konu proje ile sayım süresinin kısaltılması amaçlanmıştır. Ayrıca; drone ile yapılacak stok kontrolünün sağladığı avantajlar belirlenmiştir. .Drone teknolojisinin depoda kullanılmasıyla birlikte lokasyon başına sayım süresinin 26,69 adam/saniyeden 10.94 adam/saniyeye düşeceği saptanmıştır. İş sağlığı ve güvenliği açısından risk barındıran durumlar ortadan kaldırılarak sayım süreci ile alakalı ' 0 ' iş kazası olması hedeflenmiştir. Drone (insansız hava aracı) kullanılarak sayım yapılması durumunda iş yükünde \%59 adam/saat kazanç beklenmektedir. Geliştireceğimiz süreç ile birlikte her bir lokasyonun ortalama sisteme giriş süresinin \%35 oranında düşürülmesi hedeflenmektedir. Sahada geçirilen sürenin toplam sayım süresine oranı ise, mevcut durumda \%70 iken planlanan süreç ile birlikte \%51 olacaktır. (Karahan, 2018)

Ayrıca sayım süresini kısaltmak ve hataları en aza indirmek maksadıyla kamera ile lokasyonların fotoğraflarının çekilmesi ve daha sonra çekilen fotoğrafların ürün etiketleri kullanılılarak bilgilerin depo yönetim sistemine anlık olarak aktarılabildiği bir sistem projeler arasında yer almaktadır. Bu kapsamda Otonom robotlar ile yatay ve dikey entegrasyon kullanılacak teknolojiler arasındadır.

Stok kontrol aşamasında; öncelikle endüstri 4.0 teknolojileri ile entegre olabilecek bir depo yönetim programı ile birlikte, iş kazaları azaltmak, zaman ve işgücü tasarrufu sağlamak, stok maliyetlerini minimuma indirmek, insan kaynaklı oluşabilecek kazaları önlemek maksadıyla; anılan teknolojilerin hepsi kullanılabilir. Ancak mutlaka kullanılması gereken teknolojileri sıralayacak olursak; otonom robotlar, yatay ve dikey entegrasyon ve bulut teknolojileridir.

Stok kontrol süreçlerini en basit şekilde ele alırsak; insan gücünü tamamen ortadan kaldırmak için stok kontrol süreçlerinde otonom robot teknolojileri olmazsa olmaz teknolojiler arasındadır. Insan gücünün yerini robotlar alacak ve depoda her türlü faaliyette insan gücü devre dışı bırakılacaktır. Daha sonra depo faaliyetlerini gerçekleştiren robot stok kontrol süreçlerinde elde ettiği bilgileri paylaşmak amacıyla başka bir sisteme aktaracak ve sistemlerin birbiri ile entegre olmasını sağlayacaktır. Bu aşamada yatay ve dikey entegrasyon teknolojisi kullanılacaktır. Elde edilen bilgiler gerektğinde kullanılmak üzere bir bulutta depolanacaktır.

Stok kontrol aşamasında kullanılacak endüstri 4.0 teknolojilerini belirlerken; öncelikle işletmelerin ihtiyaçları göz önünde bulundurulmalıdır. İşletme özelliğine ve ihtiyaçlarına göre teknolojiler belirlenir. Bu kapsamda görüşme yapılan işletmenin 
Endüstri 4.0 teknolojilerini belirlerken; işletmenin en önemli parametre olarak üzerinde durduğu iş güvenliği ve iş sağlığı konuları etkili olmuştur. İ̧̧ güvenliği ve iş sağlığı konuları dışında, işletmenin stok maliyetini minimuma indirmesi; stok kontrol aşamalarının çok fazla zaman alması, insan kaynaklı yapılan sayımlarda genel olarak hataların oluşabilme riskinin bulunması, insan kaynaklı sayımlarda geri dönük izlemenin mümkün olmaması gibi etkenler temel nedenler arasında yer almaktadır. İ̧letme, bahse konu stok kontrol süreçlerinde oluşan ihtiyaçları karşılamak maksadıyla projeler geliştirmiştir.

Görüşme yapılan işletmenin çalışan odaklı olması ve çalışanın iş güvenliği ön planda tutması açısından, stok kontrol süreçlerinin geliştirilmesinde ana neden olmuştur. Farklı bir işletme tamamen maliyet faktörünü ön planda tutarak kendine uygun teknolojileri geliştirebilirdi. Bu nedenle işletme ihtiyacının ana nedeni farklı teknolojilerin gelişmesini sağlayacaktır.

İşletme, hâlihazırda manuel olarak stok kontrolü yapmaktadır. Mauel olarak yapılan stok kontrolünde, "reach truck" olarak adlandırılan depo araçlarına sepet takılarak, sepet üzerine çıkıp üst raflara ulaşan personelin ürünleri saymasıyla gerçekleştirilmektedir. Stokların kontrol edilmesi, sayımı yapan personelin sayım sonuçları ile depo yönetim programındaki ürün miktarlarının karşılaştırıması sureti ile yapılmaktadır. Ancak; Sepet kullanılarak sayım yapılması: halihazırda depolarda sayım aşamasında depo çalışanının yüksek raf lokasyonlarındaki ürünleri sayma amacı ile kullanılan sayım sepetlerinin, yüksekte çalışma koşullarının iş sağlığı ve güvenliği açısından riskler barındırması, yine klasik ve manuel yöntemlerin kullanılması, insan hatasına açık olmasından nedeniyle kullanımı uygun görülmemiştir.

Ayrıca işletmede kullanılan diğer stok kontrol sistemleri manlift (insan asansörü) ve RFID etiketlerinin kullanılmasıdır. Ancak insan asansörü olarak da bilinen manliftlerin hareket kabiliyetinin sınırlı olması ve kontrol süreçlerinde fazla zaman alması sebebiyle kullanımı uygun görülmemiştir. RFID etiketlerin okutularak stok kontrolünün yapılması depodaki paletlerin işletmeye ait olmaması oluşacak yüksek maliyet, depolarda metal yoğunluğunun yüksek olması, sahada oluşacak radyasyon ve sistemin kontrolü için ek bir kontrol sürecinin gerekliliği gibi işletmeye özel nedenlerden dolayı kullanımı uygun görülmemiştir.

İşletmenin mevcut durumda kullandığı stok kontrol sistemleri incelendiğinde, manuel olarak kontrol yapılmasından dolayı hata riskinin oluştuğu, işçi güvenliğini tehlikeye atabilcek pozisyonların zaman zaman oluştuğu, işletmelerin stok kontrolü için personelin mesai sonrası zamanını aldığı, işletme için ilave işgücü maliyeti yaratıldığı, depo miktarları ve depo yönetim sistemindeki miktarlar arasından uyuşmazlıkların oluştuğu yaşanan problemler arasındadır.

İşletmede stok kontrol süreçlerinde oluşan problemleri çözmek amacıyla çağa uygun teknolojilerden faydalanılarak stok kontrol sistemleri oluşturulmuştur. Stok kontrol süreçleri ve endüstri 4.0 uygulamaları daha da geliştirilererk ortak bir payda da birleştirildiğinde; belkide bugün kullandığımız birçok sistem ve iş gücü ortadan kalkacaktır. Geliştirilecek sistemleri üretim yapan işletmeler için ele alacak olursak; Üretim yönetimi miktar, kalite, zaman ve maliyet için en uygun değeri bulmaya çalışır. Farklı bir deyiş ile üretim yönetimi mamullerin; miktar, özellik, yer ve zaman açısından değerlendirildiğinde en düşük maliyeti sağlayan çözümü bulmaya ve bu sayede; tüketici isteklerini fiyat, zaman, miktar ve kalite açısından en iyi şekilde karşılamaya, mümkün olduğu kadar stok düzeyini düşük tutmaya veya stok devirlerini arttırmaya, işletmenin kas gücü ve makina kaynaklarından yararlanmasını arttırmaya çalışır. (Kobu, 2014)

Üretim yönetiminin amaçlarından da anlaşıldığı gibi, işletme faaliyetlerinin en uygun değerle gerçekleştirilmesinde stoklar üretim yönetiminde önemli bir yere sahiptir. Stok yönetimi açısından konuyu ele alacak olursak, üretim yönetiminin en uygun değere ulaşmasında, stok düzeylerinin minimum seviyede tutulması gerekmektedir.

Ayrıca talepler, işletmelerin bulunduracakları stok miktarını şekillendirir. Bu sebeple, işletmeler stok seviyelerini, minimum seviyede tutabilmek için öncelikle talep tahminlerini en doğru şekilde yapmalıdır. Dolayısıyla bir işletme stok miktarını belirleyebilmesi için, öncelikle oluşacak talep miktarını öngörmesi gerekmektedir ve geliştirilecek stok kontrol sistemleri talep tahmini yapabilecek nitelikte olmalıdır. Örneğin siber fiziksel sistem teknolojileri sayesinde; akıllı ürünlerin sahip olduğu bilgi taşıyan işlemci, tanımlanabilir bileşenler ve gömülü detektör özellikleri sayesinde ürünler gerçek zamanlı olarak izlenebilecek ve ürüne oluşabilecek talep tahminleri yapılabilecektir. Müşterilerin üretim süreçlerine dahil edilmesiyle işletmeler, müşterilerini tanıyacak ve müşteri ihtiyaçlarına göre ürün stoklayacaktır. Siber-fiziksel üretim sistemleri, sadece organizasyonel süreçlerin otomasyonu için değil, aynı zamanda bakım faaliyetlerinde de kullanılabilecektir. Siber fiziksel sistemlerin kullanımı ile taleplerde, stok seviyesinde veya hatalarda meydana gelen değişikliklere hızlı bir şekilde tepki verilebilecek ve bu durum genel atık azaltımını sağlayacaktır. (Uglovskaia, 2017)

İsletmeler tarafından talep tahminlerinin yapılmasında veya gelişen teknolojilerle net olarak belirlenmesinde, RFID sistemlerinden yararlanılabilir. RFID sistemleri sayesinde ürünlerin içine gömülü kimliklerin okunmasıyla depoda stoklanacak her türlü hammadde ve malzemeye var olduğu ilk andan itibaren izlenebilir. Bu sayede kullanıcı durumları ölçülebilir ve buna bağlı olarak ürüne oluşacak talep ortaya çıkabilir. Böylece işletmeler piyasada oluşacak talep dalgalanmaları da önceden tahmin ederek gerekli tedbirlerini alabileceklerdir. Bu durum aynı zamanda işletmelerin bulundurması gereken stok miktarını da net 
olarak bilmesini sağlayacaktır. En basit anlamda düşünüldüğünde bile endüstri 4.0 teknolojilerinin kullanılması işletmenin birçok işlemini ortadan kaldıracak ve zaman kaybını önlecektir.

İşletmelerin insan gücü yerine kullanacağı otonom robotlar sayesinde; servis robotları fabrikalar, depolar, hastaneler ve diğer halka açık alanları dolaşarak üretim süreci boyunca parçaları ve malları getirmek, ürünleri taşımak, palet yüklemek gibi işlerinin yanı sıra makinelerin ve stokların durum düzeylerini kontrol etmek amacıyla bağımsız veya insan asistanı olarak çalışabilecektir. (Fırat, 2017) Birbirleriyle iletişim halinde olan makine ve robotlar büyük üretim serilerinin pratik bir şekilde üretilmesine imkân tanıyacak ve esnek fabrikaların oluşmasını sağlayacaktır. İleri otomasyonda (insansız üretim hatlarında), benzetim ve veri tekniklerinin kullanımıyla üretim hızı artacak, ihtiyaç duyulan stok miktarları azalacak, bu durum da verimliliğin artmasını sağlayacaktır. (Pamuk ve Soysal. 2017)

Tablo 3: Endüstri 4.0 Destekli Stok Kontrol Uygulamaları

\begin{tabular}{ll}
\hline Endüstri 4.0 Teknolojileri & $\begin{array}{l}\text { Endüstri 4.0 Destekli Stok Kontrol Sistemlerinin } \\
\text { Uygulamaları }\end{array}$ \\
\hline Otonom Robotlar & Ürünleri toplama, paketleme ve kaldırma amacıyla kullanılır. \\
\hline Simülasyon & $\begin{array}{l}\text { Depoda sanal test ortamlarının yaratılması ve çalışanların } \\
\text { eğitilmesi amacıyla kullanılır. }\end{array}$ \\
\hline Eklemeli Üretim & Hammadde veya mamul malların özelleştirilmesi. \\
\hline Artırılmış Gerçeklik & $\begin{array}{l}\text { Akıllı gözlükler ile ürün toplama ürün paketleme ve sıralama } \\
\text { gibi işler yapılmaktadır. }\end{array}$ \\
\hline Yatay ve Dikey Entegrasyon & Iş̧letmelere ortak çalışma alanı sağlar. \\
\hline Nesnelerin İnterneti & $\begin{array}{l}\text { Sensörler vasıtasıyla depoda tarama, izleme bağlantı kurmayı } \\
\text { sağlar. }\end{array}$ \\
\hline Siber Fiziksel Sistemler & $\begin{array}{l}\text { Bir depoda tutarlı operasyonlar sağlamak, veri hırsızlığını } \\
\text { önlemek amacıyla kullanılır. }\end{array}$ \\
\hline Bulut & $\begin{array}{l}\text { Düşük maliyetle bilgi depolamaya ve paylaşmaya yardımcı } \\
\text { olur. }\end{array}$ \\
\hline Büyük Veri Analitiği & $\begin{array}{l}\text { Veri akışlarının (gönderi bilgileri, hava durumu, trafik vb.) } \\
\text { akıllı korelasyonu yoluyla analiz edilmesini sağlar. }\end{array}$ \\
\hline
\end{tabular}

Not: (Pamuk ve Soysal, 2017)'den yazarlar tarafından uyarlanmıştır

Talep tahminleri yapılarak, stokun net olarak belirlenmesinden bir adım daha öteye gidersek, fabrikaların ihtiyaç duyduğu malzemelerin endüstri 4.0'ın getirdiği katmanlı üretim sayesinde gerçekleşebilir mi? Bu soru aslında endüstri 4.0 geleneksel yöntemlerden biri olarak sunulan tam zamanında üretimi destekleyecek mi sorusunu da beraberinde getirmektedir.

Ancak gelecekte her işletme için stok bulundurmama ya da gerektiğinde katmanlı üretimden faydalanılarak ihtiyaçların karşılanması gibi durumlar söz konusu olmayabilir. Bu durumda depo içinde stoklanan ürünlerin mutlaka stok kontrollerinin ve malzeme ihtiyaç planlamalarının yapılması gerekir.

Endüstri 4.0 teknolojileri kullanılarak oluşturulacak tüm stok kontrol sistemlerinde mutlaka bir çok departman birbiri ile iletişim halinde olmalıdır. Endüstri 4.0 beraberinde getirdiği birçok teknoloji ile, tedarikçiden hammaddenin alınmasından, malzemenin yarı mamul veya mamul haline getirilip nihai tüketiciye ulaşıncaya kadar olan süreçlerde anlık olarak bilgi edinmenin mümkün olduğunu göstermiştir.

Şirketler, fabrikalar, tedarikçi, lojistik, kaynaklar, müşteriler vb. arasında yatay ve dikey entegrasyon ile oluşturulabilecek bir yapı sayesinde, tüm veriler bulutta toplanabilir. Bulut sayesinde bilgisayarların yükü hafifletilerek her türlü veri depolanabilir. Tüm departmanlar istedikleri veriye, istedikleri yer ve zamanda sahip olabilirler. Oluşacak bu yatay ve dikey entegrasyon sayesinde satışlar, stok seviyeleri, talepler vb. gibi bir çok bilgiye anlık olarak ulaşılabilir.

Bu kapsamda, Endüstri 4.0'ın stok kontrolü üzerindeki etkileri aşağıda belirtilen tablodaki gibi belirlenmiştir. 
Tablo 4: Endüstri 4.0 ve Stok Kontrol Sistemleri ilişkisi

\begin{tabular}{|c|c|c|}
\hline Endüstri 4.0 Teknolojileri & & $\begin{array}{l}\text { Endüstri 4.0 Destekli Stok Kontrol Sistemlerinin } \\
\text { Uygulamaları }\end{array}$ \\
\hline Otonom Robotlar & \multirow{4}{*}{$\begin{array}{l}\text { Fiziksel Alanlarda } \\
\text { Uygulamaları }\end{array}$} & $\begin{array}{l}\text { Ürünleri toplama, paketleme ve kaldırma } \\
\text { amacıyla kullanılır. }\end{array}$ \\
\hline Simülasyon & & $\begin{array}{l}\text { Depoda sanal test ortamlarının yaratılması ve } \\
\text { çalışanların eğitilmesi amacıyla kullanılır. }\end{array}$ \\
\hline Eklemeli Üretim & & $\begin{array}{l}\text { Hammadde veya mamul malların } \\
\text { özelleştirilmesi. }\end{array}$ \\
\hline Artırılmış Gerçeklik & & $\begin{array}{l}\text { Akıllı gözlükler ile ürün toplama ürün paketleme } \\
\text { ve sıralama gibi işler yapılmaktadır. }\end{array}$ \\
\hline Yatay ve Dikey Entegrasyon & \multirow{5}{*}{ Siber Alanlardaki Uygulamaları } & İşletmelere ortak çalışma alanı sağlar. \\
\hline Nesnelerin Interneti & & $\begin{array}{l}\text { Sensörler vasıtasıyla depoda tarama, izleme } \\
\text { bağlantı kurmayı sağlar. }\end{array}$ \\
\hline Siber Fiziksel Sistemler & & $\begin{array}{l}\text { Bir depoda tutarlı operasyonlar sağlamak, veri } \\
\text { hırsızlığını önlemek amacıyla kullanılır. }\end{array}$ \\
\hline Bulut & & $\begin{array}{l}\text { Düşük maliyetle bilgi depolamaya ve } \\
\text { paylaşmaya yardımcı olur. }\end{array}$ \\
\hline Büyük Veri Analitiği & & $\begin{array}{l}\text { Veri akışlarının (gönderi bilgileri, hava durumu, } \\
\text { trafik vb.) akılı korelasyonu yoluyla analiz } \\
\text { edilmesini sağlar. }\end{array}$ \\
\hline
\end{tabular}

Endüstri 4.0 kapsamında çalışmak isteyen yöneticilerin göz önünde bulundurması gereken durumlar ise, endüstri 4.0 ile ilgili stratejilerin dikkatle belirlenmesi, endüstri 4.0 kavramının ve getireceği avantaj, dezavantajların farkında olunarak planlama yapılması ve bu planlama kapsamında doğru elemanlar ile uygulama sürecine gidilmesi gerekliliğidir.

\section{SONUÇ}

Lojistik, geçmişten günümüze kadar olan süreçte yaşamımızın her alanında fayda sağlamıştır. Yaşamımızın akışını değiştiren ve yaşamımızı kolaylaştıran teknolojik buluşlar ile coğrafi keşifler lojistiğin gelişimine de katkı sağlamıştır. (Acar ve Köseoğlu, 2014). Coğrafi keşifler ile gelişip günümüze kadar gelen lojistikte bugün yeni bir dönem açılmış ve yeni bir kavram olarak endüstri 4.0 ortaya çıkmıştır. Endüstri 4.0 teknolojilerinin kullanılmasıyla hayatımızda birçok şeyin değişeceği öngörülmektedir. Bu değişikliklerin öncelik endüstri 4.0'ın da başlangıcı olarak kabul edilen üretim sistemlerinden başlayıp daha sonra tedarik zinciri içinde birçok alana yayılması beklenmektedir. Stok kontrol süreçleri de bu alanlardan bir tanesidir.

Endüstri 4.0 teknolojilerinin stok kontrol süreçlerinde kullanılmasıyla gelecekte stok kontrol sistemleri yeni bir boyut kazanacaktır. Stoklanacak malzeme miktarı ve çeşidinin azalması, insan faktörü olmadan kontrollerin yapılması, bazı fabrikaların tamamen stoksuz üretime geçmesi gibi düşünceler bunlardan bazılarıdır. Ayrıca, üretim yapan işletmeler dışında insan kullanılmadan, işletmelere maliyet ve işgücü açısından maksimum fayda sağlayacak sistemler geliştirilmektedir ve geliştirilecektir. Yapılan çalışmada endüstri 4.0 konseptinin çok yeni olmasından dolayı işletmeler henüz endüstri 4.0 ile anılan teknolojilerden tam anlamıyla yararlanamamaktadır. Ancak, ihtiyaçlarının ve çağın gerekliliklerinin farkında olan işletmeler yakın zamanda endüstri 4.0 ile bambaşka bir çalışma ritmi yakalayacaklardır. Gelecekte, Endüstri 4.0 ile öngörülen üretim ortamı sağlandığında belki de bugün geliştirmeyi düşündüğümüz birçok stok kontrol yöntemi yerini tamamen siber fiziksel sistemlerle donatılmış depolara bırakacak ve biz ihtiyaç duyduğumuz her bilgiye kısa zamanda ve anlık olarak ulaşabileceğiz.

Yukarıda bahsedilen hususlar göz önünde bulundurulduğunda stok kontrol süreçlerinde birbiri ile entegre sistemlerin kullanılması işletmelere ilave maliyeti ve zaman kaybını ortadan kaldırması beklenmektedir. Ayrıca depolarda yapılan sayımların çalışan personel açısından ilave iş yükü ve iş güvenliğini olumsuz etkileyen bir unsur olarak görülmesi de ortadan kalkacaktır. Endüstri 4.0 destekli stok kontrol modellerinin, depo yönetim sistemleri ile entegre olması halinde lojistik süreçlerin daha hızlı ve tutarlı bir şekilde yürütülmesi tahmin edilmektedir.

Müşteri memnuniyeti açısından değerlendirildiğinde; siber Fiziksel Sistem Teknolojieri ile endüstri 4.0 müşterileri, üretici tarafından belirlenen sabit bir aralıktan ürün seçmek zorunda kalmayacak, aksine gerekli fonksiyonları ve bileşenleri tek tek birleştirerek kendi ürünlerini üretebileceklerdir. (Uglovskaia, 2017) Robotlar Teknolojieri sayesinde; vücuda yerleştirilebilir (implant) ve giyilebilir teknolojiler, insanların dijital varlıklarını artıracak, nesnelerin birbirleriyle etkileşime girmelerini 
sağlayacaktır. (Alçın ,2016) Nesnelerin İnterneti ile müşteriler ürünlerine uzaktan bağlanabilir, çeşitli yazılım uygulamaları ile onları denetleyebilir. Müşterilere proaktif bakım hizmetleri sağlanır. Bu durumda, imalatçı müşteri alanındaki ürünü uzaktan izler; ürünün ne zaman bakıma ihtiyacı olduğunu bilmek için toplanan verileri kullanır. Bunun sonucunda belirli zamanlarda onarım ve servis planlar ve gerçekleştirir. Müşteriler ani olarak gelişen bakım ihtiyaçları ile karşı karşıya gelmez. Böylece müşteriler zamandan tasarruf sağlayabilir. Bulut teknolojileri sayesinde saklamak istediğimiz veriler bilgisayarımızda yer kaplamadan depolanabilmektedir. Ayrıca, bu sistemler sayesinde bir başka cihazdan bilgilere ulaşma, indirme ve kullanma gibi işlemler yapılabilmektedir. (Uglovskaia, 2017) Büyük veri sistemleri bilginin görünür olmasını sağlar. İşletmeler ve tüketiciler için maliyet avantajı sunar. Sınırsız depolama kapasitesi ile her yerde mevcut bilgi işlem gücünün kullanılmasına yardımcı olur.

Yatay ve Dikey Entegrasyon ile üretici ve müşterileri taleplerinin karşılanmasında birbirleri ile bağlantılı ve tam entegre sistemlerin olması üretici ve müşteriler açısından zaman tasarrufu sağlayabilir. Yatay ve dikey entegrasyon sayesinde, müşteri önerileri ve taleplerinin hızlıca değerlendirilmesi müşterilerin kendilerine özel ürünlere sahip olmalarını sağlayacaktır. Bu durumun yüzde yüze yakın bir müşteri memnuniyeti sağlaması kaçınılmazdır. Yatay birleşme hammadde tedarikinden pazarlama satış aşamasına kadar tam kapasitede çalışma sağlamakla birlikte maliyetlerin de düşmesi müşteriler tarafından arzu edilen bir durumdur. Makineler doğrudan bilgisayar modellerinden çalışacak, böylece müşteriler mevcut üretim sınırlamaları olmadan benzersiz şekiller talep edebileceklerdir. Eklemeli üretim yardımıyla tüketiciler üretici olabilecektir. Müşterilerin prototip ve sanal simülasyon yoluyla erken tasarım aşamasında ürünleri test etmelerini sağlar. Ürünlerden alınan geri bildirim ile ürün hataları tespit edilebilir. Ayrıca ürünler için proaktif algılama ve kalite kontrol işlemlerinin gerçekleştirilmesini mümkün kılmaktadır.

\section{KAYNAKLAR}

Acar, Z., Köseoğlu, M. (2014). Lojistik yaklaşimiyla tedarik zinciri yönetimi. Nobel Yayıncılık, 1.Basım, Ankara.

Alçın, S. (2016). Üretim için yeni bir izlek: sanayi 4.0. Journal of Life Economics, sayı 8, s:19-30.

Ayanoğlu, M. (2005). Üretim yönetimi (Ders Notları). Adapazarı: Sakarya Kitabevi, s.336

Bozkurt, Ü. İ., Durdu, A. (2016). Akıllı fabrikalarda dağitilmiş kontrol sistemleri uygulamasi ve RFID yaklaşımı.

Çevik, C. (2012). Lojistik yönetiminde stok kontrolü ve dinamik stok kontrol modellerinin karşilaştirmali olarak bir işletmede analizi. Yüksek Lisans Tezi, s.57-58.

Çiftçibaşı, (2009). RFID sistemlerde güvenlik açıklari ve çözüm yolları. STM A.Ş E”lektrik Mühendisliği, Sayı: 437.

Doğan, İ. (1995). Yöneylem araştirmasi teknikleri ve işletme uygulamaları. İstanbul: Bilim Teknik Yayınevi.

Doğruer, M. (2005). Üretim organizasyonu ve yönetimi. İstanbul: Alfa Basım Yayım.

Ege, (2014). Endüstri 4.0 devrimi kapida mı? Bilim ve Teknik Dergisi, Mayıs Sayısı.

Ertuğrul, İ., Tanrıverdi, Y. (2013). Stok kontrolde ABC yöntemi ve AHP analizlerinin iplik işletmesine uygulanması. Uluslararası Alanya İşletme Fakültesi Dergisi, C:5, Sayı:1, s.41-52.

Günay, S. ( 2005). Lojistik yönetim ve stok kontrolünde Silver Meal modelinin uygulanması. Yüksek Lisans Tezi, Dumlupınar Üniversitesi Sosyal Bilimler Enstitüsü, Kütahya.

Geliş, H., Ersoy, A. R. (Erişim Tarihi: 15.04.2018). Endüstri 4.0 yolunda Siemens endüstri 4.0 yolunda. siemens.com.tr/dijitalfabrikalar

Kahraman, G., Öztürk, M., Köseoğlu, M. A. (2018). Insansiz hava araci ile depo sayim sisteminin stok kontrolüne etkileri. IRDITECH, Okan Universitesi İstanbul.

Kahraman, H. (05.04.2018). Bulut bağlantili robotlar ve endüstri 4.0 ,http://www.endustri40.com/bulut-baglantili-robotlar-ve-endustri-4-0/

Kobu, B. (2014). Üretim yönetimi. Beta Yayınevi, 17. Baskı İstanbul.

Lee, J., Kao, H., Yang, S. (2014). Service innovation and smart analytics for industry 4.0 and big data environment.

Maraşlı, F., Çıbuk, M. (2015). RFID teknolojisi ve kullanim alanları.

Fırat, O. Z., Fırat, S. Ü. (2017). Endüstri 4.0 yolculuğunda trendler ve robotlar. İstanbul Üniversitesi İşletme Fakültesi Dergisi Vol/Cilt: 46, No/Sayı:2, s.211-223.

Pamuk, N. S., Soysal, M. (2017). Yeni sanayi devrimi endüstri 4.0 üzerine bir inceleme.

Qina, J., Liua, Y., Grosvenora, R. (2016). A categorical framework of manufacturing for industry 4.0 and beyond. 
Rüßmann, M., Lorenz, M., Gerbert, P., Waldner, M., Justus, J., Engel, P., Harnisch, M. (2015). Industry 4.0: The future of productivity and growth in manufacturing industries.

Sezen, B. (2004). Tedarik zincirinde stok yönetimi problemleri için elektronik tablolar yardımı ile simülasyon uygulaması. Yönetim ve Ekonomi Cilt:11 Sayı:1.

Sulak, (2008). stok kontrolü ve ekonomik sipariş miktari modellerinde yeni açilimlar: ödemelerde gecikmeye izin verilmesi durumu ve bir model önerisi. Doktora Tezi, Süleyman Demirel Üniversitesi, Sosyal Bilimler Enstitüsü, Isparta.

Tanyaş, M., Baskak, M. (2006). Üretim planlama ve kontrol. 2. Yayın, İstanbul: İrfan Yayımcılık.

Viale, J. D. (1996). Basics of inventory management: from warehouse to distribution center.

Wang, S., Wan, J., Li, D., Zhang, C. (2016). Implementing smart factory of industrie 4.0: an outlook. International Journal of Distributed Sensor Networks, 12(1), 3159805.Yazıcl, A., (2016). Endüstri 4.0 ve otonom robotlar. 2Eskişehir Osmangazi Üniversitesi Bilgisayar Mühendisliği Bölümü ve Yapay Zeka ve Robotik Laboratuvarı.

Yıldız, T. (2017). Yaklaşan dördüncü endüstri devrimi ve Türkiye'deki mevcut durum. 10.13140/RG.2.2.31022.82242/1.

Zuehlke. (2010). SmartFactory-towards a factory-of-things. Annual Reviews in Control. 